\title{
Chapter 2 \\ Beyond the Grave Breaches Regime: The Duty to Investigate Alleged Violations of International Law Governing Armed Conflicts
}

\author{
Amichai Cohen and Yuval Shany
}

\section{Contents}

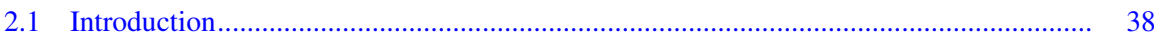

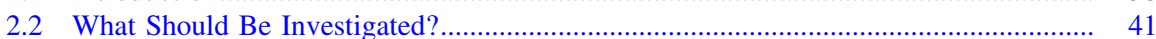

2.2.1 The Non-Exclusive Nature of the Grave Breaches Regime Under IHL........... 41

2.2.2 Human Rights Law as a Complementary Sourceof the Duty to Investigate..... 48

2.2.3 Triggering Mechanisms ............................................................................... 51

2.2.4 State Practice ..................................................................................... 52

2.2.5 Interim Conclusions ................................................................................ 55

2.3 Investigation Standards Governing All Forms of Investigation ............................... 56

2.3.1 Standards of Investigation Under IHL ............................................ 56

2.3.2 Standards of Investigation Under the ICC Statute .................................. 57

2.3.3 The Internal Logic of the Duty to Investigate .............................................. 58

2.3.4 The Contents of the Duty to Investigate Under International

Human Rights Law .............................................................................. 58

2.4 How States Maintain in Practice the Independence and Impartiality of Their

Systems of Military Investigations .................................................................... 64

2.4.1 State Practice Suggestive of Robust Independence Standards ......................... 66

2.4.2 State Practice Standing in Tension with the Principle of Independence .......... 70

2.4.3 The Recent Israeli Debate Over the Independence and Impartiality of its System of Military Investigations

We would like to thank Noa Amirav and Ido Rosenzweig for their research assistance.
A. Cohen $(\square)$
Faculty of Law, Ono Academic College, Kiryat Ono, Israel
e-mail: amichai.cohen@gmail.com
A. Cohen · Y. Shany
Israel Democracy Institute, Jerusalem, Israel
Y. Shany
Hersch Lauterpacht Chair in Public International Law, Hebrew University, Jerusalem, Israel e-mail: shany.yuval@gmail.com


2.4.4 Interim Conclusions

2.5 Operationalizing a Broad Duty to Investigate: Reconciling Tensions Between

Different Investigation Tracks

2.5.1 Problems with the Criminal Investigation of IHL and IHRL Violations........... 75

2.5.2 The Use of Non-Criminal Accountability Mechanisms:

Independent Commissions

2.6 Conclusion

References

\subsection{Introduction}

The observation that international humanitarian law (IHL) does not need more rules, but rather better enforcement mechanisms has become somewhat of a universally accepted mantra, as well as a call for action. ${ }^{1}$ Indeed, the last quarter of a century has witnessed considerable progress in the strengthening of IHL enforcement procedures: new international criminal courts with jurisdiction over certain IHL issues have been established ${ }^{2}$; universal and other forms of criminal jurisdiction have been exercised by a growing number of states during and in the aftermath of numerous armed conflicts ${ }^{3}$; and military lawyering has been expanded in scope and deepened in reach in many national militaries. ${ }^{4}$ In addition, it has become widely-accepted that international human rights law (IHRL) continues to apply in situation of armed conflict, at least with regard to persons situated under the effective control of the relevant states. ${ }^{5}$ As a result, IHRL courts and committees have increasingly asserted their authority over armed conflicts. ${ }^{6}$

Given the clear potential for the involvement of military personnel in violations of the rules applicable in armed conflicts, on the one hand, and the capabilities of militaries for exercising effective control over soldiers, on the other hand, it is only natural that military legal institutions are deemed to be an important, if not the most important, line of defense against violations of international law perpetrated

\footnotetext{
${ }^{1}$ See e.g., ICRC 2007, p. 721 ("in the ICRC's view, the main cause of suffering during armed conflicts and of violations of IHL remains the failure to implement existing norms-whether owing to an absence of political will or to another reason-rather than a lack of rules or their inadequacy").

2 Mackenzie et al. 2010, Chapter 3.

${ }^{3}$ Example: The International Criminal Court for Former Yugoslavia (ICTY); The International Criminal Court for Rwanda (ICTR).

${ }^{4}$ See e.g., Newton 2007, Dickinson 2010.

5 See e.g., Ben-Naftali 2011, p. 3.

${ }^{6}$ Example: Abresch 2005, Byron 2007.
} 
during armed conflicts. ${ }^{7}$ Arguably, a robust system of military investigations and prosecutions may prevent future violations (inter alia, through generating deterrence and removing repeat offenders from the battlefield), and punish those who have committed them in the past. Such a system can also help in identifying organizational and procedural deficiencies that may have permitted IHL violations to take place to begin with.

The increased focus on the structures and procedures of military investigative mechanisms-reflected in part in the growing scrutiny of such mechanisms by judicial bodies applying human rights standards ${ }^{8}$ - has led many militaries to reevaluate the manner in which they investigate allegations of international law violations occurring during armed conflict. Thus, a number of legal and institutional reforms have been launched in recent years-Canada established new investigative bodies in $1997^{9}$ and Australia followed suit in $2007^{10}$; the UK in 2006 adopted a new Armed Forces Act ${ }^{11}$; and the US issued new Directives on investigations in 2011. Furthermore, almost a 100 countries have created national IHL committees to supervise their implementation efforts ${ }^{12}$; and in other countries, such as Israel, a robust public debate has revolved around the proper scope and nature of the duty to investigate military acts (an official commission and inquiry, as well as the national Supreme Court, have reviewed the matter in Israel). ${ }^{13}$

Notwithstanding these developments, there remain fundamental questions about the duty to investigate violations of international law applicable in situations of armed conflict. For example, what should be the investigative trigger and how and

${ }^{7}$ Example: Article 82 of the First Additional Protocol (Protocol Additional to the Geneva Conventions of 12 August 1949, and Relating to the Protection of Victims of International Armed Conflicts, 8 June 1977, 1125 UNTS 3) (AP I) requires militaries to "ensure that legal advisers are available, when necessary, to advise military commanders at the appropriate level on the application of the Conventions and this Protocol and on the appropriate instruction to be given to the armed forces on this subject."

${ }^{8}$ See e.g., Isayeva, Yusopova and Bazayeva v. Russia, Judgment of 24 February 2005, no. 57947-49/00 ECHR, 2005; Issa v. Turkey, Judgment of 16 Nov.2004, no. 31821/96 ECHR 2004; Al Skeini v. UK, Grand Chamber, Judgment of 7 July 2011, no.55721/07 ECHR 2011.

9 National Defence Act, R.S.C. 1985, c. N-5 (Can.).

10 Defence Act 1903 (2006 amendments) Defense Instructions 2007 available at: http://www.defence.gov.au/fr/Policy/ga67_02.pdf. Some parts of the 2006 act were challenged before the High Court of Australia. On 29 August 2009 the High Court of Australia ruled that the newly created Australian Military Court was unconstitutional: Lane v. Morrison [2009] HCA 29 (26 August 2009).

11 UK Armed Forces Act 2006.

12 http://www.icrc.org/eng/resources/documents/misc/table-national-committees.htm.

13 See HCJ 9594/03 B'Tselem and Association for Civil Rights in Israel v. Military Advocate General, Judgment of 21 August 2011 (in Hebrew); http://www.turkel-committee.gov.il/ index.html. The Mandate of the Turkel commission includes, inter alia, review of the question whether the military investigation mechanisms addressing complaints and allegations regarding violations of the laws of war meet Israel's international obligations. 
to what extent are human rights principles governing criminal investigations during peacetime transposable to the military context? What is the relationship between the duty to undertake criminal investigations and to engage in other factfinding exercises? And how do principles of military necessity and proportionality affect the scope and contents of any duty to investigate? As will be shown below, state practice on these issues diverges, and it has been argued that for some questions no international standards exist at all. ${ }^{14}$ Furthermore, a few of these questions seem to have escaped, by and large, the attention of judges and commentators, although their practical importance may be significant.

The purpose of the present article is to critically evaluate the contemporary international law obligation to investigate military conduct in times of conflict and to identify relevant normative trends. In a nutshell, we argue that the traditional focus on the Geneva grave breaches regime in the context of military investigations is misplaced. The duty to investigate is far broader encompassing alleged violation of many other norms of IHL and IHRL and engaging the responsibility of both military and civilian officials. It is also more diverse in its objective and richer in its methods than sometimes has been assumed. Thus, for example, some allegations would justify a criminal investigative response whereas others may merit alternative reactions, such as disciplinary proceedings, civil proceedings or some other fact-finding process. What is more, some of these responses are primarily geared towards ensuring personal accountability for past deeds, while others are more concerned with improving future practices. Nevertheless, we are of the view that all reactions to alleged violations, as well as the mechanism for selecting between them, should be governed by IHRL principles (such as independence, impartiality, promptness and transparency), although their manner of application to battlefield investigations would necessitate adjustment.

Section 2.2 of the article (after this introduction) discusses the breadth of the duty to investigate. It shows that the duty extends far beyond the grave breaches regimes and discusses, in that context, the necessary triggering mechanisms. Section 2.3 discusses the main legal standards governing military investigationsgenuineness, effectiveness, independence and impartiality, promptness and transparency. Section 2.4 addresses trends in international legislation and state practice concerning the maintenance of independence under the challenging conditions featured in many military investigations. Section 2.5 explains the reasons supporting the move away from criminal enforcement in some cases and sketches a possible solution to some of the practical problems identified in this article-the establishment of a permanent commission of inquiry for evaluating IHL compliance in military operations. Section 2.6 concludes.

${ }^{14}$ Schmitt 2011. 


\subsection{What Should Be Investigated?}

\subsubsection{The Non-Exclusive Nature of the Grave Breaches Regime Under IHL}

There is little question that states must investigate serious allegations of war crimes committed by individuals subject to their jurisdiction with a view to ascertaining the criminal responsibility of the suspected perpetrators. This rule, found in the grave breaches provisions of the Geneva Conventions, ${ }^{15}$ is also supported by the jurisprudence of human rights courts on violations of the right to life and the prohibition against torture, stipulating a second order "effective remedy" obligation to respond through criminal investigation and prosecution to serious IHRL violations by state agents as well as other perpetrators. ${ }^{16}$ Even so, the claim sometimes made, explicitly or implicitly, that the military is required under international law to investigate only allegations of grave breaches ${ }^{17}$ appears to us erroneous for the following reasons.

First, the grave breaches provisions of the Geneva Conventions entail much more than a duty to investigate and prosecute soldiers accused of committing war crimes. They also contain the following obligations: (1) to enact suitable criminal legislation $^{18}$; (2) not to absolve perpetrators of grave breaches from legal responsibility ${ }^{19}$; and, most significantly, (3) to search and prosecute (or extradite) any individual-regardless of his or her nationality - that allegedly committed grave breaches. ${ }^{20}$ Hence, the main effect of the grave breaches provisions appears to be the internationalization of war crimes (a process further enhanced by the inclusion of grave breaches provisions in the statutes of international criminal tribunals-including the International Criminal Court (ICC)). ${ }^{21}$ The claim that the

\footnotetext{
15 Geneva Convention for the Amelioration of the Condition of the Wounded and Sick in Armed Forces in the Field, 12 August 1949, Article 49, 75 UNTS 31 (GC-I); Geneva Convention for the Amelioration of the Condition of Wounded, Sick and Shipwrecked Members of Armed Forces at Sea of August 12, 1949, Article 50, 75 UNTS 85 (GC-II); Geneva Convention Relative to the Treatment of Prisoners of War of August 12, 1949, Article 129, 75 UNTS 135 (GC-III); Geneva Convention Relative to the Protection of Civilian Persons in Times of War of August 12, 1949, Article 146, 75 UNTS 287 (GC-IV); AP-I, Article 85.

16 See e.g., Velasquez Rodriguez v. Honduras, Judgment of July 29, 1988, Inter-Am.Ct.H.R. (Ser. C) No. 4 (1988), at para 176.

17 Schmitt 2011.

18 GC I, Article 49; GC II, Article 50; GC III, Article 129; GC IV, Article 146, AP-I, Article $85(5)$.

19 Ibid.

20 Ibid.

21 Statute of the International Criminal Tribunal for Former Yugoslavia, 25 May 1993, Article 2, UN Doc. S/RES/827 (1993)(ICTY Statute); Statute for the International Criminal Tribunal for Rwanda, 8 Nov. 1994, Article 4, UN Doc. S/RES/955 (1994)(ICTR Statute); Statute of the International Criminal Court, 17 July 1998, Article 8(2)(a), 2187 UNTS 90 (ICC Statute).
} 
state's duty to investigate and prosecute violations committed by its own military is co-extensive with its obligations to exercise criminal jurisdiction over any crime committed by any person, anywhere in the world, is not dictated by either the terms of the grave breaches provision nor by their internal logic. In fact, the opposite seems to be true. Alongside the specific obligation to suppress grave breaches through a particularly aggressive criminal law response (formal legislation, no exoneration, universal jurisdiction-subject to the aut dedere aut judicare principle) the Conventions require states to address through appropriate means other violations of the Convention. As explained below, we are of the opinion that such appropriate means may entail, in certain circumstances, criminal investigations and prosecutions.

The proposition that the Geneva Conventions and their Additional Protocols impose a broad duty to investigate going beyond situations in which grave breaches have been allegedly committed is borne out by a close reading of the terms of the grave breaches provisions themselves, and is supported by the parallel language used in the First Additional Protocol.

All four grave breaches provisions contain the following language:

Each High Contracting Party shall take measures necessary for the suppression of all acts contrary to the provisions of the present Convention other than the grave breaches defined in the following Article. ${ }^{22}$ (emphasis added)

Thus, alongside the specific obligations to exercise criminal jurisdiction under the grave breaches regime, the Conventions introduce a general obligation of taking measures necessary for suppression of other violations (in the original French text-prendra les mesures nécessaires pour faire cesser les actes contraires aux dispositions de la présente Convention). Indeed, the Pictet Commentary to the Geneva Conventions clarifies that the drafters did not intend the grave breaches regime to limit the general duty to investigate and prosecute (which covers all violations of the Conventions):

Article 29 of the 1929 Convention called for the punishment of 'all' acts contrary to the provisions of the Convention, and there could be no question of the Diplomatic Conference of 1949 not going as far as in 1929 .... It is thus clear that 'all' breaches of the present Convention should be repressed by national legislation. At the very least, the Contracting Powers, having arranged for the repression of the various grave breaches and fixed an appropriate penalty for each, must include a general clause in their national legislative enactments, providing for the punishment of other breaches of the Convention. Furthermore, under the present paragraph the authorities of the Contracting Parties should issue instructions in accordance with the Convention to all their subordinates, and arrange for judicial or disciplinary proceedings to be taken in all cases of failure to comply with such instructions. ${ }^{23}$

${ }^{22}$ GC I, Article 49; GC II, Article 50; GC III, Article 129; GC IV Article 146.

23 Pictet 1958, vol. I at pp. 367-368. Pictet also notes that there is a certain overlap between the obligation to investigate and prosecute other violations, and the specific duty to repress abuses of the emblem, specified in Article 54 of the First Geneva Convention. Like the grave breaches regime, Article 54 does not exhaust the obligations of the member states in the field of norm enforcement. 
In the same vein, Article 86(1) of the First Additional Protocol provides that:

The High Contracting Parties and the Parties to the conflict shall repress grave breaches, and take measures necessary to suppress all other breaches, of the Conventions or of this Protocol which result from a failure to act when under a duty to do so. (emphasis added)

Although the duty to suppress other breaches under Article 86(1) appears to be limited to omission-type violations, this must be understood in light of the duty imposed on military commanders in Article 87 to prevent all violations of the Conventions and the Protocol by persons subject to their control. ${ }^{24}$ Hence, the combination of Articles 86 and 87 establishes a general duty to suppress all violations - certainly going far beyond the grave breaches regime.

Developments in international criminal law in the 1990s, involving the expansion of war crimes beyond the grave breaches specified in the Geneva Conventions and the First Additional Protocol, underscore the non-exclusivity of the grave breaches regime as a basis for criminal prosecutions under international law: The International Criminal Tribunal for the Former Yugoslavia (ICTY) has been authorized to prosecute violations of the laws and customs of war other that grave breaches of the Geneva Conventions ${ }^{25}$ - a mandate that was interpreted by the Appeals Chamber as encompassing “ any serious offence against international humanitarian law" not covered by the other provisions in the Statute (referring to grave breaches, crimes against humanity and genocide). ${ }^{26}$ A similar mandate going beyond the grave breaches regime can be found in, for instance, the statutes of the International Criminal Tribunal for Rwanda (ICTR), the Special Court for Sierra Leone (SCSL) and the ICC. ${ }^{27}$ The trend towards enumerating lists of international crimes subject to the jurisdiction of international courts that go beyond the grave breaches regime implies a fortiori that national legal systems should also treat these other serious violations as justifying a criminal response. This is especially so given the rising expectation that international criminal courts

\footnotetext{
24 AP 1, Article 87(1) reads: "The High Contracting Parties and the Parties to the conflict shall require military commanders, with respect to members of the armed forces under their command and other persons under their control, to prevent and, where necessary, to suppress and to report to competent authorities breaches of the Conventions and of this Protocol."

25 ICTY Statute, Article 3.

${ }^{26}$ ICTY, Prosecutor v Dusko Tadić, Decision on the Defence Motion for Interlocutory Appeal on Jurisdiction, Appeals Chamber I (IT-94-1-AR72) 2nd October 1995, para 91.

27 ICTR Statute, Article 4 ("The International Tribunal for Rwanda shall have the power to prosecute persons committing or ordering to be committed serious violations of Article 3 common to the Geneva Conventions of 12 August 1949 for the Protection of War Victims, and of Additional Protocol II thereto of 8 June 1977”); Statute of the Special Court for Sierra Leone, 16 Jan. 2002, Articles 3, 4, http://www.sc-sl.org/LinkClick.aspx?fileticket=uClnd1MJeEw\%3d\& tabid=176 (SCSL Statute)(authorizing the court to try individuals who committed serious violations of common Article 3, and the Second Additional Protocol to the Geneva Conventions, as well as three other serious violations of IHL); ICC Statute, Article 8(2)(b)-(e).
} 
adhere to the principle of complementarity thereby leaving the bulk of investigations and prosecutions in the hands of national authorities. ${ }^{28}$

The need to investigate serious violations of international humanitarian law beyond the grave breaches regime is further supported by three key principles embraced in the Geneva Conventions and Additional Protocols: (1) The general duty to ensure respect of the Conventions (or principle of effectiveness), ${ }^{29}$ (2) the command responsibility doctrine, ${ }^{30}$ and (3) the precautionary obligations of the parties to the conflict. ${ }^{31}$ It is also supported, though less clearly, by the duty to respond to allegations of violations made by the other party to the conflict. ${ }^{32}$

\subsubsection{Ensuring Respect for IHL}

Common Article 1 to the four Geneva Conventions requires the Contracting Parties to "respect and to ensure respect for the present Convention[s] in all circumstances"; similar provisions can be found in the First Additional Protocol. ${ }^{33}$ According to the Pictet Commentary this entails, inter alia, a duty to supervise the execution of the Conventions, ${ }^{34}$ a point with which the commenters of the Additional Protocols concur. ${ }^{35}$ The duty to ensure respect for IHL was deemed by the ICRC Study to constitute part of customary international law. ${ }^{36}$

Investigation of serious violations of IHL can be viewed as an indispensible means by which to effectively carry out the duty to ensure respect for IHL. As is well known, the International Military Tribunal in Nuremberg was of the view that criminal prosecutions are an essential strategy for enforcing international law obligations: "Crimes against international law are committed by men, not by abstract entities, and only by punishing individuals who commit such crimes can the provisions of international law be enforced." 37 Indeed, criminal investigations and prosecutions may promote respect for IHL through increased deterrence and the physical removal of offenders from the battlefield. Other considerations, including learning from operational misdeeds in order to avoid future violations

\footnotetext{
28 On the issue of complementarity, see Holmes 1999, Danner 2003, p. 526.

29 GC I, Article 1; GC II, Article 1; GC III, Article 1; GC IV, Article 1.

30 AP-I, Article 87, ICC Statute, Article 28.

31 Example: AP-I, Articles 57, 58.

32 AP-I, Article 89.

33 AP1, Article 1(1).

34 Pictet 1958, vol I, at 26 ("It would not, for example, be enough for a State to give orders or directives to a few civilian or military authorities, leaving it to them to arrange as they pleased for the details of their execution. It is for the State to supervise their execution").

35 Sandoz et al. (1987), Article 1, para 41. See also AP 1, Article 80(1).

36 Henckaerts and Doswald-Beck 2005, Rule 139, p. 495.

37 Judgment of the International Military Tribunal at Nuremberg, 30 Sept.-1 Oct. 1946, I Trial of the Major War Criminals before the International Military Tribunal (1947) 223.
} 
and the second-order obligation to satisfy victims of violations, ${ }^{38}$ also militate in favor of an expansive duty to investigate as an effective method to ensure respect for IHL.

As will be explained below, since the duty to ensure respect is relative in nature-circumscribed, inter alia, by resource constraints-states may legitimately decide, at times, to implement the duty to ensure respect through the pursuit of non-criminal avenues of investigation (such as disciplinary proceedings or fact-finding inquiries). In fact, we will claim that non-criminal investigations are sometimes more conducive to ensuring future compliance with IHL than criminal proceedings. Hence, notwithstanding the Nuremberg dicta, the duty to ensure respect for IHL does not mandate a duty to launch a criminal investigation for each and every alleged violation of IHL. However, at least for serious violations, there ought to be a strong presumption in favor of investigation entailing both legal accountability for past events and forward-looking pressure to prevent future unlawful acts (or omissions).

\subsubsection{Command Responsibility}

Another source for a broad duty to investigate IHL violations can be found in the institution of command responsibility, specified in Articles 86, 87 of the First Additional Protocol and accepted now, by and large, as part of customary international law. ${ }^{39}$ The command responsibility doctrine requires military commanders to "to prevent and, where necessary, to suppress and to report to competent authorities breaches of the Conventions and of this Protocol" 40 Whereas considerable attention has been afforded in the legal literature and the case law of international criminal tribunals to the criminal law implications of dereliction on the part of commanders to prevent or punish war crimes (in particular, following the introduction of a superior responsibility in Article 28 of the ICC Statute), ${ }^{41}$ far less attention has been given to the duty to investigate and prosecute imposed on military commanders in connection with violations not amounting to grave breaches For our purpose, it is clear that the broad duty to prevent and suppress-encompassing all breaches of the Geneva Conventions and the First Additional Protocol_-implies a concomitant obligation on the state party

\footnotetext{
38 Hague Convention concerning the Laws and Customs of War on Land, 18 October 1907, Article 3, 3 Martens Nouveau Recueil (ser. 3) 461 (Hague Convention/Regulations); International Covenant on Civil and Political Rights, 16 Dec. 1966, Article 2(3), 999 U.N.T.S. 171 (ICCPR).

39 Henckaerts and Doswald-Beck 2005, Rule 153 p. 558.

40 AP I, Article 87(1).

41 Shany and Michaeli 2002; Ronen 2010, pp. 313-356; ICTY, Prosecutor v Zejnil Delalić, Zdravko Mucić, Hazim Delić, and Esad Landžo ("Čelebići “), Judgment of the Appeals Chamber (IT-96-21-T) 20th February 2001, pp. 54-104; ICTY, Prosecutor v. Sefer Halilović, Judgment of the Appeals Chamber (IT-01-48-A)16 October 2007.
} 
to conduct criminal or disciplinary investigations and prosecutions in appropriate cases.

Once a violation of the Convention and/or First Additional Protocol is expected to occur or has already occurred, military commanders are required to take active steps to prevent and suppress the said violations. Article 87(3) explicitly provides that the duty to suppress involves, "where appropriate, to initiate disciplinary or penal action against violators thereof." In other words, with regard to violations of IHL other than grave breaches, military commanders are expected to resort to one of following responses: criminal measures, disciplinary measures, or-where appropriate - other measures not necessarily entailing individual responsibility; such measures are to be taken by the commander herself or by other competent authorities. $^{42}$

In any event, the investigation of alleged violations is integral to the carrying out of the commander's duty to prevent and suppress. This is because investigation of past violations would allow the commander to make an informed decision as to what would be, under the circumstances, the appropriate response to the alleged violation $^{43}$; such an investigation may also facilitate changes in the conduct of the military unit in question that would prevent future violations.

\subsubsection{The Principle of Precaution}

The broad duty to investigate violations can also be anchored in the precautionary obligations of the parties to the conflicts. Article 57(1) of the First Additional Protocol prescribes that "[i]n the conduct of military operations, constant care shall be taken to spare the civilian population, civilians and civilian objects." In the same vein, Article 57 (2)(a)(ii) of the First Additional Protocol provides that the parties should "take all feasible precautions in the choice of means and methods of attack with a view to avoiding, and in any event to minimizing, incidental loss of civilian life, injury to civilians and damage to civilian objects." Both obligations are closely related to the "least injurious means" prong of the

42 See e.g., ICTY, Prosecutor v. Ljube Boškoski and Johan Tarčulovski, Judgment of the Trial Chamber (IT-04-83-T) 10 July 2008 ("A superior's duty to punish the perpetrators of a crime may encompass an obligation to conduct an effective investigation with a view to establishing the facts. The obligation to investigate translates into an obligation on the part of the superior to take active steps to ensure that the perpetrators will be punished. To that end, the superior may exercise his own powers of sanction, or if he lacks such powers, report the perpetrators to the competent authorities. It has been held in the jurisprudence of the Tribunal that civilian superiors, who may lack the disciplinary or sanctioning powers of military commanders, may discharge their obligation to punish by reporting to the competent authorities whenever a crime has been committed if these reports are likely to trigger an investigation or initiate disciplinary or criminal proceedings").

43 See Sandoz et al. (1987), Article 87, para 3560 (“[The commanders'] role obliges them to be constantly informed of the way in which their subordinates carry out the tasks entrusted them, and to take the necessary measures for this purpose"). 
proportionality test - that is, the requirement that parties select among all possible measures that similarly advance their military goals those measures that cause the least humanitarian harm. Investigation of past incidents in which harm has occurred is arguably part of the "constant care" which parties are expected to demonstrate in order to assess on an ongoing basis the proportionate nature of the methods and means of warfare they employ. In other words, monitoring the effects of military actions through investigation of possible violations arguably constitutes a "feasible precaution" against excessive harm.

The Israeli Supreme Court, which relies heavily on the principle of proportionality in its major decisions on IHL, has identified an obligation to investigate targeted killing operations, apparently in the context of a harm mitigation rationale:

[A]fter an attack on a civilian suspected of taking an active part, at such time, in hostilities, a thorough investigation regarding the precision of the identification of the target and the circumstances of the attack upon him is to be performed (retroactively). That investigation must be independent ... In appropriate cases it is appropriate to pay compensation as a result of harm caused to an innocent civilian. ${ }^{44}$

\subsubsection{Duty to Address Request for an Inquiry}

Finally, one may link the duty to investigate alleged violations of IHL, albeit tenuously, to the duty to accommodate requests for an inquiry made by another party to the conflict and/or to pay compensation for violations. ${ }^{45}$ Arguably, allegations of violations raised by one party to a conflict require the other party to consider, in good faith, the need to initiate an investigation into the allegations. ${ }^{46}$ Similarly, the duty to compensate victims of violations may imply an antecedent duty to investigate alleged violations. However, practice explicitly involving these provisions is virtually non-existent thus, weakening the force of the proposed interpretative constructions ${ }^{47}$

\footnotetext{
44 The Public Committee Against Torture in Israel v. Gov't of Israel, Judgment of 14 Dec. 2006, H.C.J. 769/02, available at http://elyon1.court.gov.il/files_eng/02/690/007/a34/02007690.a34.pdf, at para 40.

45 See e.g., AP 1, Article 91 ("A Party to the conflict which violates the provisions of the Conventions or of this Protocol shall, if the case demands, be liable to pay compensation. It shall be responsible for all acts committed by persons forming part of its armed forces"); GC 3, Article 132 ("At the request of a Party to the conflict, an enquiry shall be instituted, in a manner to be decided between the interested Parties, concerning any alleged violation of the Convention"); Hague Convention, Article 3 ("A belligerent party which violates the provisions of the said Regulations shall, if the case demands, be liable to pay compensation. It shall be responsible for all acts committed by persons forming part of its armed forces").

46 For the general obligation to carry out treaty obligations in good faith, see Vienna Convention on the Law of Treaties, 23 May 1969, Article 26, 1155 UNTS 331 (VCLT).

47 VCLT, Article 31(3)(b).
} 
In sum, there is considerable support in the central instruments comprising IHL for the proposition that states are required to investigate grave breaches, as well as other violations of IHL. This broad proposition is supported not only in legal texts but also by policy considerations since the close relationship between investigation of past violations and the need to prevent future violations renders investigation a key strategy for the effective implementation of IHL. Moreover, given the possible inter-connectedness between grave breaches and other violations (e.g., denial of POW status may facilitate the torture of detainees), investigating one category of violations may assist also in suppressing violations belonging to the other category as well. Finally, the duty to investigate all IHL violations may be independently supported by the need to satisfy victims and afford them with remedies.

At the same time, the broader aspects of the duty to investigate identified here are more flexible in nature than those appertaining to the narrower duty to investigate allegations of grave breaches. Whereas the latter implies universal jurisdiction and a duty to employ criminal law tools, the former is more localized in scope and may entail a choice of investigation technique (criminal, disciplinary, civil measures and/or fact-finding inquiry). Furthermore, even if there had been only a relative legal obligation to prosecute all violations (grave breaches and nongrave breaches) the more serious nature of grave breaches would have implies greater expectations for a stronger response to such breaches than to other IHL violations. Thus, the absence of a general legal duty to opt for a criminal response in cases of violations not constituting grave breaches is reflective both of the state of IHL and the expected correlation between the seriousness of the violation and the harshness of the response thereto.

\subsubsection{Human Rights Law as a Complementary Source of the Duty to Investigate}

There is increased acceptance that IHRL continues to apply in times of armed conflict in a manner which affords protection to individuals from the states to whose jurisdiction they are subject. ${ }^{48}$ Although there is no full consensus on the matter, the overwhelming body of legal opinion points today in the direction of the view that IHRL may apply extraterritorially to military operations conducted in foreign territories, provided that certain areas or individuals are brought under the

48 ICCPR, Article 2(1), European Convention for the Protection of Human Rights and Fundamental Freedoms, 4 Nov. 1950, Article 1, ETS 5 (ECHR). The continued applicability of human rights law during wartime was confirmed by the International Court of Justice in its Nuclear Weapons advisory opinion, as well as in the subsequent Wall and Armed Activities (Congo) cases. Legality of the Threat or Use of Nuclear Weapons, Advisory Opinion (1996) ICJ Rep 226, 240; Legal Consequences of the Construction of a Wall in the Occupied Palestinian Territory, Advisory Opinion, (2004) ICJ Rep 136, 178; Armed Activities on the Territory of the Congo (DRC v Uganda) Merits Judgment (2005) ICJ Rep 168, pp. 243-244. 
effective control of the military in question. ${ }^{49}$ Since, the International Court of Justice has indicated that in situations of parallel applicability of IHL and IHRL the former typically serves as lex specialis, IHRL norms on the duty to investigate ought to be understood primarily as gap fillers, regulating issues not addressed by IHL, or as interpretive tools, shaping the contents and manner of application of IHL. 50

Under IHRL, states are placed under two relevant sets of obligations. Whereas the duty to respect human rights imposes on states negative obligations, the duty to protect victims (sometimes couched in language prescribing a duty to secure or ensure human rights $)^{51}$ requires states, inter alia, to embrace positive measures designed to prevent the infringement of individual rights. As noted before, the investigation of past violations may fulfill an important preventive function and could thus be regarded as a necessary positive measure of protection. Indeed, General Comment 31 of the Human Rights Committee, which purports to restate the law in the field, provides that:

There may be circumstances in which a failure to ensure Covenant rights as required by article 2 would give rise to violations by States Parties of those rights, as a result of States Parties' permitting or failing to take appropriate measures or to exercise due diligence to prevent, punish, investigate or redress the harm caused by such acts by private persons or entities. ${ }^{52}$ (emphasis added)

In addition, the duty to provide effective remedy to victims of violations has been understood to contain a 'second order' obligation to offer legal or administrative remedies in response to past violations. Here too, investigations serve as the antechamber for dispensation of remedies. ${ }^{53}$

In any event, like its IHL counterpart, the duty to investigate under IHRL is an obligation of a relative nature and correlates to the seriousness of the violation and the circumstances under which it may have occurred. For example, ECHR case law on the duty to institute criminal investigations has focused almost exclusively on violations of the most fundamental human rights standards-Articles 2, 3 and 5

\footnotetext{
49 For a comprehensive discussion of the extraterritorial application of human rights law, see Milanovic 2011; Lubell 2010.

50 Ben-Naftali and Shany 2004, p. 17, Prud'homme 2007.

51 ICCPR, Article 2(1), ECHR, Article 1.

52 Human Rights Committee, General Comment 31: Nature of the General Legal Obligation Imposed on States Parties to the Covenant, UN Doc. CCPR/C/21/Rev.1/Add.13 (2004), at para 8.

${ }^{53}$ Ibid, at para 15 ("A failure by a State Party to investigate allegations of violations could in and of itself give rise to a separate breach of the Covenant. Cessation of an ongoing violation is an essential element of the right to an effective remedy"). See also Kaya v Turkey, Judgment of 28 March 2000, no.225335/93 ECHR 2000, at para 124 ("Article 13 requires, in addition to the payment of compensation where appropriate, a thorough and effective investigation capable of leading to the identification and punishment of those responsible for the deprivation of life and including effective access for the complainant to the investigation procedure").
} 
of the European Convention (the right to life, the prohibition against torture and the right to liberty). ${ }^{54}$ Furthermore, in difficult circumstances, such as conflict situations, full investigations may be impracticable either because of objective battlefield conditions or because of other pressing needs taking priority over investigations.

Indeed, a recent fact-finding committee (headed by Christian Tomuschat) appointed by the Human Rights Council to examine, inter alia, Israeli and Palestinian investigations in the aftermath of the 2008-2009 conflict in Gaza has stated as follows:

[T]here are constraints during armed conflict that do impede investigations. For example, not every death during an armed conflict can be effectively investigated ${ }^{55}$

Such constraints may justify in some cases-at least those featuring relatively minor harms - either no criminal investigation or even of any form of investigation. The same constraints may also explain, even in those cases where investigation has been initiated, the resort to sub-optimal investigative measures. ${ }^{56}$

The upshot of this analysis is that IHRL provides an independent basis for a duty to investigate harms to individuals occurring during armed conflicts. Given the breadth of the scope of rights covered by human rights treaties, which exceed in some important areas the protections afforded by IHL (for example, with respect to freedom of movement), some harmful conduct not covered by the IHL duty to investigate would nonetheless be covered by the parallel duty under IHRL. It therefore appears that, to the extent that they also compromise IHRL norms, violations of IHL norms other than grave breaches should be investigated also by virtue of IHRL; it is also clear that some violations not covered at all by IHL should nonetheless be investigated under IHRL.

In addition, to the extent that IHRL introduces more demanding investigation standards, these may supplement the requirements found in IHL unless the latter requirements are deemed as lex specialis, or if there are overriding considerations (such as military necessity) that pull in specific cases in the direction of partial application of human rights standards. In the next Part of this article we discuss and largely reject the lex specialis argument as far as it pertains to investigation requirements; we acknowledge, however, the need to engage in constant balancing between the duty to investigate and battlefield conditions.

\footnotetext{
54 Kaya v. Turkey (supra n.53); Isayeva v. Russia, supra n.8; Jordan v. United Kingdom, Judgment of 4 August 2001, no.24746/94 ECHR 2001. For a rare example of a judgment finding a duty to investigate case involving another Convention right, see Gündem v Turkey, Judgment of 16 March 2000, no.23144/93 ECHR 2000, at para 71 (state violated duty to investigate attacks against a newspaper, violating thereby freedom of expression).

55 Tomuschat report 2010, para 32.

56 Ibid.
} 


\subsubsection{Triggering Mechanisms}

Although violations of IHL and IHRL applicable in conflict situations result in a relative duty to investigate, as with other positive obligations, such a duty should be carried out with due diligence, i.e., in accordance with the legal requirements of reasonableness or appropriateness. ${ }^{57}$ The relativity of the duty to investigate implies not only that states should prioritize serious violations over less grave ones; it also suggests that they should prioritize investigating credible allegations or reasonable suspicions over those that lack credibility or unreasonable ones. As a practical matter, militaries cannot be expected to spend precious time and resources in order to investigate far-fetched or highly dubious allegations. Indeed, the European Court of Human Rights (ECtHR) in its case law on the duty to investigate allegations of disappearances and torture has established an "arguable claim" 58 or a "credible assertion" of a violation ${ }^{59}$ as the relevant triggers for investigations into alleged violations.

Still, one may posit that, at least as a matter of lex ferenda, some correlation ought to exist between the gravity of the alleged or suspected violation and the triggering requirements. ${ }^{60}$ Hence, allegations or suspicions pertaining to the most serious violations of law may require investigation even on the basis of less than fully credible allegations or well-founded suspicions. A lowering of the threshold in potentially serious cases not only ensures a higher level of humanitarian protection, it also increases the prospect that less serious violations are effectively addressed. This is because evidence, which cannot sustain allegations of serious violations (e.g., premeditated killings), may nonetheless sustain allegations of a less serious nature (e.g., negligent killings). As a result, an incident featuring serious consequences in questionable circumstances, such as unexpected loss of life or wanton harm to property without a clear justification, may warrant an investigation even if no evidence of wrongdoing is initially available.

One may find some support for this last proposition in the ECtHR's holding that every killing perpetrated by government forces must be investigated even if no

\footnotetext{
57 Koivurova 2008.

58 See e.g., Assenov v. Bulgaria, Judgment of 28 October 1998, no. 80/1997/874/1086 ECHR 1998-VIII, para 102; Ilhan v Turkey, Grand Chamber, Judgment of 27 June 2000, no. 22277/93 ECHR 2000-VII, para 97; Cyprus v Turkey, Grand Chamber, Judgment of 10 May 2001, no. 25781/94 ECHR 2001, para 132.

59 See e.g., Labita v. Italy, Grand Chamber, Judgment of 6 April 2000, no. 26772/95 ECHR 2000-IV, para 131; Khashiyev v. Russia, Judgment of 24 February 2005, nos. 57942/00 and 57945/00 ECHR, para 177.

60 Any serious violation of the right to life requires investigation, even in cases of armed conflicts: Human Rights Committee, General Comment 31 (2004), at para 18; Isayeva v. Russia (supra n.8), paras 209-212; Las Palmeras v. Colombia, I/A CHR Judgment of 6 Dec. 2001, para 65; Watkin 2004, pp. 17-20.
} 
prima facie indication of illegality is shown, ${ }^{61}$ whereas other violations of the right to life-not directly implicating the government-need to be supported by "credible allegations" of wrongfulness or involve "suspicious circumstances." 62 Although this line of decisions does not necessarily apply as a matter of lex lata to battlefield conditions (where conducting an investigation after every act of killing may be impractical), ${ }^{63}$ it does support the view that a lower threshold should be established when the most serious of violations-extrajudicial killings by governments-may have occurred.

In any event, it is clear that the duty to investigate can be triggered on the basis of suspicious circumstances, in the absence of any formal complaint or allegation. ${ }^{64}$ It is also clear that the duty encompasses both acts and omissions of direct perpetrators as well as accomplices and also extends to relevant military or civilian superiors. $^{65}$

\subsubsection{State Practice}

The broad duty to investigate described above finds some, though not full, support in actual state practice. This picture of partial compliance is characteristic of areas of law in which slow changing practices often lag behind faster moving normative developments (as for example in the recent evolution of IHRL into battlefield investigations). Partial compliance can also be explained by the weakness of IHL's enforcement machinery, which exacts limited pressure on militaries to introduce legal reforms in response to new legal standards. This lag in compliance is exacerbated by the tendency of militaries to view with some apprehension the introduction of new and onerous legal obligations that would be costly to meet and potentially limit policy options. ${ }^{66}$

Still, one may observe trends in actual state practice which point in the normative direction identified in this article. For example, the recent UK Armed Forces Act of 2006 introduces a two-layer duty to investigate: (1) A strong obligation on commanding officers to refer serious crimes (including, as specified in

\footnotetext{
${ }^{61}$ See e.g., Kaya v Turkey, supra n. 53, para 91.

62 See e.g., Silih v Slovenia, Grand Chamber, Judgment of 9 April 2009, no.71463/01 ECHR 2009, para 157, and para 4 of the joint dissenting opinion of Judge Bratza and Judge Turmen.

63 UN Report 2010, para 29.

${ }^{64}$ See e.g., Al Skeini v UK, supra n.8, para 165 ("What form of investigation will achieve the purposes of Article 2 may vary depending on the circumstances. However, whatever mode is employed, the authorities must act of their own motion once the matter has come to their attention. They cannot leave it to the initiative of the next-of-kin either to lodge a formal complaint or to take responsibility for the conduct of any investigative procedures").

${ }^{65}$ ICTY, Prosecutor v. Sefer Halilović, Judgment of the Trial Chamber (IT-01-48-T) 16 November 2005.

66 Jochnik and Normand 1994.
} 
Schedule 2 of the Act, grave breaches of the Geneva Conventions) ${ }^{67}$ to service police investigation; and (2) a weaker obligation to investigate, as appropriate, other service offences (with or without the involvement of the service police). The UK Act introduces a test of reasonableness according to which an obligation to investigate is triggered if the relevant allegations or circumstances "would indicate to a reasonable person that [an offence] has or may have been committed by a relevant person." 68

US military law does not contain a two-level obligation similar to that found in UK law. Still, the relevant 2006 Department of Defense Directive (DODD 2311.01E) introduces a putative duty to investigate that goes well beyond the grave breaches regime. Section 3.2 of the DODD broadly defines "reportable incident" in the following terms: "A possible, suspected, or alleged violation of the law of war, for which there is credible information, or conduct during military operations other than war that would constitute a violation of the law of war if it occurred during an armed conflict." 69 Note, that the duty to report incidents arises in the face of allegations or suspicions suggesting any violation of the law of war (i.e., not only grave breaches). ${ }^{70}$ In addition, the evidentiary threshold identified in the Directive is quite low-credible information suggesting a possible violation of IHL.

Australian military procedures seem to set an even lower threshold for opening some form of preliminary examination into legally questionable situations. Defence Instructions (General) Admin 67-2 of 2007 provides that a "Quick Assessment" be conducted by a service member who is free, to the maximum extent feasible, from bias or conflict of interest. Whether such an assessment is required is subject to the common sense judgment of the relevant commanders or supervisors following "an occurrence, which can be any significant incident, allegation or problem, which comes to the attention of the commander/supervisor." 71 In the same vein, a 2010 amendment to the Australian Defence Instructions (General) Admin 45-2 defines a "notifiable incident," potentially setting in motion military investigation procedures, to include inter alia (1) an incident giving rise to a reasonable suspicion that an offence was committed under the Australian Defence Force Discipline Act 1982 (except minor offences), Australian criminal law or the criminal law of another country, where the incident involves Defence personnel, property or premises ${ }^{72}$; (2) any case involving "the death, serious injury or disappearance of non-Defence personnel [excluding non-detained enemy combatants], involving any Defence activity, property or premises (even where

\footnotetext{
67 UK Armed Forces Act 2006, Schedule 2, section 12(t).

68 UK Armed Forces Act 2006, sections 113(2), 115(2).

69 Department of Defence Directive 2311.01E, May 9, 2006, section 3.2 (US).

70 Schmitt 2011, p. 70.

71 Defence Instructions (General) Admin 67-2, 7 Aug. 2007, at para 8 (Austl.).

72 Defence Instructions (General) Admin 45-2, Amdt No 1, 26 March 2010, at para 6(a), (b) (Austl.).
} 
there may be no reasonable suspicion of an offence having been committed)" "73; and (3) "an incident deemed by commanders or managers to be serious, sensitive or urgent not covered by the definitions above. As a guide, these incidents are events that may bring Defence into disrepute; attract media or Parliamentary attention; or may adversely affect the efficiency of Defence." 74

The combined effect of the different tracks for initiating investigation under Australian military law ensures that incidents giving rise to reasonable suspicions of an IHL or IHRL violation or serious incidents even raising such a possibility will be investigated by some inquiry mechanism. Of course, this broad triggering system goes well beyond the grave breaches regime. In fact, it goes even beyond the duty to investigate just IHL violations as identified in the previous section. It also supports the position that a movement may be occurring towards lowering the evidentiary requirements for opening investigation in all cases involving serious consequences.

Canadian military procedures are also generally consistent with some aspects of a broad duty to investigate violations of the laws applicable to armed conflict situations. The 2003 Joint Doctrine Manual published by the Office of the Judge Advocate-General requires commanders, in language mirroring Article 87(3) of the First Additional Protocol, to initiate disciplinary or penal proceedings if they become aware that one of their subordinates violated the laws of armed conflict. ${ }^{75}$ Furthermore, the Manual lists as war crimes, mandating criminal investigation and prosecution, violations of a number of laws of armed conflict provisions other than the grave breaches clauses of the Geneva Convention and the First Additional Protocol. ${ }^{76}$ In addition, a 1999 amendment to the Queen's Regulations and Orders for the Canadian Forces provides that a preliminary criminal investigation should be initiated whenever (1) a complaint (of a non-frivolous or vexatious nature) has been made that a service offence has been committed; or (2) when there are other reasons to believe that a service offence was committed. ${ }^{77}$ The broad scope of service offences under Canadian military law ${ }^{78}$ ensures that many violations of IHL and IHRL applicable to situations of armed conflict would be subject to a duty to investigate.

Finally, it may be noted that the Israeli Supreme Court has recently issued a short decision, rejecting a petition brought by a number of Israeli NGOs against what they considered to be excessively rigid triggering criteria applied by the

73 Ibid, at para 6(e).

74 Ibid, at para 6(f).

75 Office of the Judge Advocate-General, Joint Doctrine Manual: Law of Armed Conflict at the Operational and Tactical Levels, B-GJ-005-104/FP-021 (2003), section 1504.

76 Ibid, at section 1609.

77 Queen's Regulations and Orders for the Canadian Forces, P.C. 1999-1305 of 8 July 1999, section 106.02 .

78 See e.g., National Defence Act, R.S.C., 1985, N-5, section 77(d)(destruction of property), section 92 (disgraceful conduct), section 124 (negligent performance of duties), section 130 (offences punishable by ordinary law). 
investigation authorities of the IDF. ${ }^{79}$ The Court noted that while the case was pending, new triggering criteria had been introduced by the IDF, mandating the opening of a criminal investigation in each lethal incident involving IDF service members in the West Bank (except cases clearly qualifying as combat actions, where the decision to open a criminal investigation would depend on the findings of a preliminary inquiry). According to the Court, this change in policy has rendered the petition moot. Still, the Court did formulate a general triggering standard that delineates the scope of the duty to launch a criminal investigation under Israeli law in cases involving loss of life (both in times of peace and at time of war). Such a duty now arises whenever death may have resulted from an unlawful conduct $^{80}$ - a test potentially covering both violations of IHL and IHRL. The Court also held that the inability to pursue a criminal investigation does not relieve the state of its obligation to identify some other avenue of redress, including a change in policy or financial compensation. Thus, non-criminal investigations may be required in certain circumstances not involving the loss of life and/or indications of illegality.

\subsubsection{Interim Conclusions}

In sum, we find clear indications in recent doctrine, as well as in recent state practice, that the duty to investigate goes well beyond the grave breaches regimes and encompasses both criminal and non-criminal responses to violations of international law applicable in situations of armed conflict. This development appears to be supported by weighty policy considerations. While grave breaches most certainly need to be investigated, prosecuted and punished, many if not most IHL and IHRL violations occurring during situations of armed conflicts-especially involving the regular armed forces of "rule of law" countries-do not qualify as grave breaches. Yet, although negligent designation of military targets, reckless endangerment of enemy civilians or skewed proportionality analysis may not qualify always as a war crime (or proven to be committed with criminal intent), such acts or omissions may be systemic in nature and reflective of an official governmental policy. It cannot be ruled out that the harm to humanitarian interests caused by these chronic lower-level violations may far outweigh the harm caused by grave breaches per se.

Consequently, when discussing the strengthening of IHL and IHRL enforcement mechanisms, our focus should not be exclusively directed at the grave breaches regimes; instead, we should also look closely at how national institutions are handling the bulk of other IHL and IHRL alleged violations. This may include less dramatic responses to violations than criminal investigations, such as

79 B'Telem v. Military Advocate General, supra n. 13.

80 Ibid, at para 10. 
disciplinary measures, civil proceedings and fact-finding inquiries. As will be shown below, it is with respect to this latter category of more moderate responses that IHRL can particularly enrich and reinvigorate IHL.

\subsection{Investigation Standards Governing All Forms of Investigation}

Even if states were to agree that investigations are indeed required in a specific instance, the question which then arises pertains to the form of the investigation. What form should an investigation into allegations or suspicions of IHL or IHRL violations take? The purpose of this part of the article is to identify the minimum requirements for investigation under IHL and IHRL. As no IHL treaty directly addresses the issue at hand, we first direct our attention to sources of IHL which indirectly regulate it. We then examine the relevant contents of the duty to investigate as developed under IHRL. Finally, we comment on the practices of some states engaged in the investigation of allegations or suspicions of IHL or IHRL violations. The examination of law and practice may enable us to inject some concrete contents into the somewhat abstract duty to investigate.

\subsubsection{Standards of Investigation Under IHL}

No IHL treaty text explicitly addresses the requirements for a proper investigation into allegations or suspicions of IHL violations. However, the doctrine of command responsibility under IHL may introduce implicit obligations that can assist us in specifying the contents of the IHL duty to investigate.

As mentioned earlier, the doctrine of command responsibility requires commanders to suppress all violations of IHL, a duty which is interpreted as requiring investigations where appropriate. Under this doctrine commanders are required to investigate (or refer to the competent investigation authorities) violations of IHL committed by their subordinates with a view to identifying past IHL violations and suppressing future violations. In those cases where criminal sanctions are required (i.e. grave breaches of the Geneva Conventions and other serious violations) the purpose of the investigation is also to facilitate punishing the perpetrators of these violations.

The case law of international criminal tribunals on command (or superior) responsibility throws some light on the principles that govern these investigation objectives. In the ICTY Boskoski and Turcalovski case, the duty of commanders to punish their subordinates who committed IHL violations was understood to encompass: "an obligation to conduct an effective investigation with a view to establishing the facts" (emphasis added). ${ }^{81}$ The decision does not specify,

81 ICTY, Prosecutor v. Ljube Boškoski and Johan Tarčulovski, supra n. 42, at para 418. 
however, what elements are integral to an effective fact-finding process. In the same vein, the ICC Pre-Trial Chamber in Bemba opined that the measures taken by the superior in response to IHL violations must be "necessary and reasonable." 82 Again, the Court did not define what would constitute necessary and reasonable measures of investigation and punishment; it merely noted that the application of this standard that must be assessed "in concreto" 83 -i.e., on a case-by-case basis.

The following segments try to offer some concrete contents to the general standards of effectiveness, necessity and reasonableness identified by the ICTY and ICC. Arguably, such contents can be derived from the ICC Statute (by way of analogy), the internal logic of the duty to investigate, IHRL and state practice.

\subsubsection{Standards of Investigation Under the ICC Statute}

As already mentioned, the ICC may try cases involving violations of certain IHL norms. ${ }^{84}$ However, the Court's jurisdiction is limited by the principle of complementarity, which bars the ICC from investigating and prosecuting cases properly investigated by relevant states. Arguably, investigative acts deemed proper by the ICC for the purpose of satisfying the requirements of complementarity could be viewed as effective, necessary and reasonable also for the purpose of the satisfying the duty to investigate under IHL. At the same time, it may well be the case that national legal systems are required to adopt higher standards of investigation than the minimum requirements found in the ICC Statute. According to this view, assumption of jurisdiction by the ICC in lieu of national legal system can be understood as a reaction only to serious deviation from the standards of investigation. Under both alternatives, however, failure to meet the standards for a proper investigation identified in the ICC Statute would suggest that the duty to investigate was not properly carried out.

According to Article 17(1)(a) of the ICC Statute, the Prosecutor cannot initiate a case if:

The case is being investigated or prosecuted by a State which has jurisdiction over it, unless the State is unwilling or unable genuinely to carry out the investigation or prosecution.

The meaning of "genuine" is explained in subsection (2) of the same article:

(a) The proceedings were or are being undertaken or the national decision was made for the purpose of shielding the person concerned from criminal responsibility for crimes within the jurisdiction of the Court referred to in Article 5;

82 ICC, Prosecutor v Jean Pierre Bemba, Decision Pursuant to Article 61(7)(a) and (b) of the Rome Statute on the Charges of the Prosecutor Against Jean-Pierre Bemba Gombo, Pre-Trial Chamber II (ICC-01/05-01/08-424) 15 June 2009, para 440.

83 Ibid, para 443.

${ }^{84}$ ICC Statute, Article 8. 
(b) There has been an unjustified delay in the proceedings which in the circumstances is inconsistent with intent to bring the person concerned to justice;

(c) The proceedings were not or are not being conducted independently or impartially, and they were or are being conducted in a manner which, in the circumstances, is inconsistent with an intent to bring the person concerned to justice.

From the above text it is clear that, at the minimum, a "genuine" investigation for complementarity purposes should be bona fide in nature, prompt, independent and impartial. We discuss below all of these notions.

\subsubsection{The Internal Logic of the Duty to Investigate}

The application of the aforementioned requirements for a proper investigationgood faith, promptness, independence and impartiality, is also supported by the internal logic of the duty to investigate and legitimacy considerations. As we already mentioned, a principle objective of the duty to investigate is to prevent future IHL violations by punishing the perpetrators of past violations. It is difficult, if not impossible, to conceive of an effective and legitimate manner in which the duty to investigate can be carried which lacks good faith, independence and impartiality or reasonable promptness. An investigation that fails to genuinely strive to ascertain the truth and to hold accountable wrongdoers would not be effective or legitimate; an investigation which is not independent and impartial might not be bona fide in nature and is unlikely to be effective and legitimate; finally, a slow investigative process raises concerns about its genuineness (as suggested in Article 17(2)(b) of the ICC Statute), and may be ineffective in identifying past violations (due to the loss of evidence and fading memory) and prevent future violations. It is not surprising in light of inter-connectedness of the various requirements for a proper investigation that some of the most influential military manuals allude explicitly or implicitly to some or all of these requirements. ${ }^{85}$

\subsubsection{The Contents of the Duty to Investigate Under International Human Rights Law}

The above survey reveals that the duty to investigate violations is indeed part of IHL. It also establishes that certain general principles pertaining to the manner in which this duty ought to be executed can be deduced from IHL, the ICC Statute and the duty's internal logic. Still, further development of these general principles is necessary in order to enable us to flesh out a concrete set of practices that

${ }^{85}$ See e.g., Bill and Marsh 2010, p. 36. 
militaries would be expected to follow. Otherwise, the compliance pull attendant to the duty to investigate is likely to remain relatively low. ${ }^{86}$

It is against this background that the more developed norms relating to the duty to investigate found under IHRL should be considered. The invocation of IHRL standards can be justified not only as a particularly persuasive analogy based on the substantive proximity between the situations regulated by IHL and IHLR (a second order obligation imposed on governments in response to harm to protected individuals or individual interests by government agents); it is also supported by the co-application of IHRL and IHL in many (though not all) armed conflict situations.

Still, the different degrees of 'fit' between IHL and IHRL and conflict situations underlie the preferred status of IHL as lex specialis under international law, ${ }^{87}$ with the pride of place it affords the principle of military necessity. As a result, the application of the duty to investigate under IHRL should be viewed as lex generalis that can be modified in light of the relevant rules and principles of IHL; in the same vein, actual battlefield conditions may require adjustments to conflict situations of the manner in which human rights violations are normally investigated. ${ }^{88}$

Still, we understand the lex specialis/lex generalis relationship between the IHL and IHRL duties to investigate as implying that IHRL norms on the duty to investigate should apply in armed conflict, as in all other cases involving human rights violations, as long as there are no compelling reasons to modify their manner of application. These compelling reasons may derive from the rules of IHL (e.g., the permissibility of certain targeting decisions under IHL may obviate the need to investigate them under IHRL), the difference between the formulas employed by IHL and IHRL in cases involving balancing between military necessity and humanitarian interests (e.g., the greater tolerance for collateral damage under IHL or the lesser weight IHL attributes to transparency in military matters), or practical problems in conducting battlefield investigations.

In those cases of parallel applicability, the more developed rules of investigation under IHRL can serve to complement the more general principles found in IHL; but even when IHRL is not applicable, its norms may offer an important source for inspiration in interpreting the general principles of IHL on the duty to investigate. In both cases, however, IHRL standards should be invoked carefully,

\footnotetext{
${ }^{86}$ On the relationship between compliance and norm-specificity, see Franck 1990, p. 62.

87 Nuclear Weapons, supra n.48, p. 240.

88 As Schmitt puts it: "Evidence may have been destroyed during the hostilities, civilian witnesses may have become refugees or internally displaced persons, military witnesses may be deployed elsewhere or be engaged in combat, territory where the offense occurred may be under enemy control, forensic and other investigative tools may be unavailable on or near the battlefield, military police may be occupied by other duties such as prisoner of war handling, legal advisers may be providing conduct of hostilities advice, judicial bodies may be distant from the theatre of operations, communications may be degraded, travel may be hazardous, and so forth"-Schmitt 2011, at p. 54.
} 
respecting the normative and circumstantial differences between the two legal branches. Furthermore, as in other instances, the exact content of the duty to investigate must be examined in light of the specific circumstances ruling at the relevant time and place. ${ }^{89}$

\subsubsection{Specific Duties in International Human Rights Law}

The substance of the duty to investigate under in IHRL appears in two principal sources. The first source is a variety of soft law instruments, which purport to apply universally; the second is the rich jurisprudence of the ECtHR on this issue.

\section{Soft Law Sources}

In 2005 the UN General Assembly adopted by consensus a set of "Basic Principles and Guidelines on the Right to Remedy and Reparations for Victims of Violations of International Human Rights and Serious violations of International Humanitarian Law."90 According to this instrument, the duty to investigate must be exercised in a manner that is effective, prompt, impartial and thorough. Interestingly enough, the 2005 Principles purport to cover investigations under IHRL, as well as under IHL. Other UN resolutions have identified effectiveness, independence, impartiality and promptness as the core principles of the duty to investigate under IHRL. ${ }^{91}$

The principles governing the duty to investigate under IHRL appear to have become generally accepted and the 2009 report of the UN Fact Finding Mission on the Gaza Conflict (the Goldstone Report) termed them "universal principles" of investigation. $^{92}$

\footnotetext{
89 In the Blaskic case, the Appeal Chamber of the ICTY stated that: "The Appeals Chamber considers that $[\ldots]$ a determination of the necessary and reasonable measures that a commander is required to take in order to prevent or punish the commission of crimes, is dependent on the circumstances surrounding each particular situation"-ICTY, Prosecutor v. Tihomir Blaškić, Judgment of the Appeals Chamber (IT-95-14-A) 29 July 2004, para 417.

90 The Basic Principles and Guidelines on the Right to Remedy and Reparations for Victims of Violations of International Human Rights and Serious violations of International Humanitarian Law, 16 Dec. 2005, UN Doc. A/RES/60/147 (2006).

91 Principles on the Effective Prevention and Investigation of Extrajudicial, Arbitrary and Summary Executions, 24 May 1989 (Economic and Social Council Resolution 1989/65, annex); Principles on the Effective Investigation and Documentation of Torture and Other Cruel, Inhuman or Degrading Treatment or Punishment, 4 Dec. 2000 (General Assembly Resolution 55/89, annex).

92 Goldstone Report 2009, para 1814. Schmitt 2011.
} 


\section{ECtHR Jurisprudence}

The most elaborate discussion of the specific contents of the duty to investigate under IHRL, and its applicability to armed conflict situations, can be found in the rich jurisprudence of the ECtHR. The European Court issued in recent years a number of judgments addressing situations that may qualify as armed conflicts, including the Russian operations in Chechnya, ${ }^{93}$ British operations in Iraq $^{94}$ and Turkish attempts to curb Kurdish activity in its South-Eastern border with Iraq. ${ }^{95}$ In all of these cases, the court applied certain IHRL norms (found in the European Convention on Human Rights (ECHR)), while noting that the situation before it is not one of ordinary law enforcement. While not explicitly discussing the applicability of IHL norms, the Court was clearly aware of the need to attenuate the contents of the relevant IHRL obligations in light of the realities of armed conflict situations.

For instance, in its seminal Isayeva judgment (2005), ${ }^{96}$ the ECtHR laid down the basic principles of investigation under the ECHR (which mirrors in large parts of its contents other IHRL instruments, such as the International Covenant on Civil and Political rights (ICCPR)). According to the Court, any investigation must include the following criteria: independence, effectiveness, promptness, and some degree of public scrutiny. The Court refined these four criteria in its post-Isayeva jurisprudence, ${ }^{97}$ including in the Al Skeini judgment. ${ }^{98}$ Since the Al Skeini case dealt with events that took place in Iraq during its occupation by the US-UK led coalition, the Court directly addressed in its judgment the relationship between IHL and IHRL $^{99}$ :

\footnotetext{
93 Abresch 2005.

94 Example: Al Jedda v. UK, Grand Chamber, Judgment of 7 July 2011, no.27021/08 ECHR 2011.

95 Example: Issa v. Tureky, supra n.8.

96 Isayeva v. Russia, supra n.8, at 836: "For an investigation into alleged unlawful killing by
} State agents to be effective, it may generally be regarded as necessary for the persons responsible for and carrying out the investigation to be independent from those implicated in the events. This means not only a lack of hierarchical or institutional connection but also a practical independence. The investigation must also be effective in the sense that it is capable of leading to a determination of whether the force used in such cases was or was not justified in the circumstances... and to the identification and punishment of those responsible... A requirement of promptness and reasonable expedition is implicit in this context. For the same reasons, there must be a sufficient element of public scrutiny of the investigation or its results to secure accountability in practice as well as in theory. The degree of public scrutiny required may well vary from case to case. In all cases, however, the victim's next-of-kin must be involved in the procedure to the extent necessary to safeguard his or her legitimate interests."

97 See e.g., Bazorkina v. Russia, Judgment of 27 July 2006, no.69481/01 ECHR 2006, para 117-119; Abuyeva v Russia, Judgment of 2 December 2010, no.27065/05 ECHR 2010, para 204-216.

98 Al Skeini v. UK, supra n.8.

99 Ibid, at para 90-93. 
The Court has held that the procedural obligation under Article 2 continues to apply in difficult security conditions, including in a context of armed conflict ... It is clear that where the death to be investigated under Article 2 occurs in circumstances of generalised violence, armed conflict or insurgency, obstacles may be placed in the way of investigators and, ... concrete constraints may compel the use of less effective measures of investigation or may cause an investigation to be delayed. Nonetheless, the obligation under Article 2 to safeguard life entails that, even in difficult security conditions, all reasonable steps must be taken to ensure that an effective, independent investigation is conducted into alleged breaches of the right to life. ${ }^{100}$

Above and beyond the general principles of investigation, the ECtHR developed the more specific contents of each and every one of these principles. The following segment will introduce, in brief, the main components of the ECtHR's jurisprudence on the different requirements of a proper investigation.

\section{Effectiveness}

In several of its decisions, the ECtHR noted that the most important component of a proper investigation is its effectiveness. ${ }^{101}$ In the Al Skeini judgment, it expanded on this issue:

[T]he investigation must be effective in the sense that it is capable of leading to a determination of whether the force used was or was not justified in the circumstances and to the identification and punishment of those responsible. This is not an obligation of result, but of means. The authorities must take the reasonable steps available to them to secure the evidence concerning the incident, including inter alia eye-witness testimony, forensic evidence and, where appropriate, an autopsy which provides a complete and accurate record of injury and an objective analysis of clinical findings, including the cause of death. Any deficiency in the investigation which undermines its ability to establish the cause of death or the person or persons responsible will risk falling foul of this standard. ${ }^{102}$

\section{Independence}

In addition to effectiveness, the Court emphasized in its case law the need for an independent investigation. Again, it address the matter in its Al Skeini judgment:

For an investigation into alleged unlawful killing by State agents to be effective, it is necessary for the persons responsible for and carrying out the investigation to be independent from those implicated in the events. This means not only a lack of hierarchical or institutional connection but also a practical independence. ${ }^{103}$

\footnotetext{
${ }^{100}$ Al Skeini, supra n.8, para 164.

101 See Ahmet Özkan v. Turkey, Judgment of 6 April 2004, no.21689/93 ECHR 2004, para 312; Isayeva, supra n.8, para 212 and the cases cited therein.

${ }_{102}$ Al Skeini, supra n.8, para 166.

103 Ibid, at para 167.
} 
In assessing the actual independence of the investigation in the specific cases discussed in the Al Skeini case, the Court found that the British authorities in Iraq failed to comply with their obligation to conduct an independent investigation. This is because the commanding officer on the ground had the power to initiate the investigation, or to terminate it (even when it was initiated by the Special Investigation Branch). ${ }^{104}$

\section{Promptness}

Promptness is another important component of the duty to investigate under IHRL identified by the ECtHR. Although, the Court recognized in its Al Skeini judgment that a prompt investigation may encounter serious difficulties during the armed conflict itself, it emphasized the need to proceed with it at reasonable speed:

A requirement of promptness and reasonable expedition is implicit in this context. While there may be obstacles or difficulties which prevent progress in an investigation in a particular situation, a prompt response by the authorities in investigating a use of lethal force may generally be regarded as essential in maintaining public confidence in their adherence to the rule of law and in preventing any appearance of collusion in or tolerance of unlawful acts. ${ }^{105}$

\section{Transparency and Public Confidence}

A number of ECtHR decisions have insisted that investigations be, as far as possible, transparent. ${ }^{106}$ Like promptness, the quest for public confidence appears to be a key consideration in favor of a transparency requirement. For example, in Özkan v. Turkey (2004), the Court held that:

For the same reasons [maintaining public confidence-AC \& YS] there must be a sufficient element of public scrutiny of the investigation or its results to secure accountability in practice as well as in theory. The degree of public scrutiny required may well vary from case to case. In all cases, however, the victim's next-of-kin must be involved in the procedure to the extent necessary to safeguard his or her legitimate interests ${ }^{107}$

The principle of transparency illustrates the need to evaluate the manner in which proper investigation principles derived from IHRL can apply to armed conflicts. Phillip Alston, while serving as the UN Rapporteur of Extrajudicial, Summary or Arbitrary Executions, laid down what he assessed to be the major principles of international law regarding the investigation of targeted killing operations, including the need for transparency:

\footnotetext{
104 Ibid, at para 172.

105 Ibid, at para 167.

106 See e.g., McKerr v. United Kingdom., Judgment of 4 May 2001, no. 29993/95 ECHR 2001III, para 148; Güleç v. Turkey, Judgment of 27 July 1998, no. 21593/93 ECHR 1998-IV, at para 82; Ŏgur v. Turkey, Judgment of 20 May 1999, no. 21594/93 ECHR1999-III, para 92.

Özkan v. Turkey (supra n. 101) paras 85-90 and 309-320 and 326-330.

107 Ahmet Özkan v. Turkey, supra n. 101, para 314.
} 
[W]ithout disclosure of the legal rationale as well as the bases for the selection of specific targets (consistent with genuine security needs), States are operating in an accountability vacuum. It is not possible for the international community to verify the legality of a killing, to confirm the authenticity or otherwise of intelligence relied upon, or to ensure that unlawful targeted killings do not result in impunity. The fact that there is no one-size-fits-all formula for such disclosure does not absolve States of the need to adopt explicit policies ${ }^{108}$

This call for transparency in operational investigations is problematic to the extent it suggests that states should publicly divulge the intelligence on which they relied for specific military actions, or even to provide specific operational guidelines (e.g., under what precise circumstances it will resort to targeted killings). Such a position appears to strongly conflict, at times, with military necessity interests and is unlikely to be heeded to by many, if not most militaries around the world. Still, as we suggest below, the problem of public scrutiny can be partly addressed in a different way-through independent mechanisms of oversight operating within the state concerned.

The above quotations from decisions of the ECtHR represent only a small sample of that body's rich jurisprudence on the duty to investigate under the ECHR. At a more general level it appears as if the principles of effectiveness, independence, promptness and public scrutiny identified by the Court are all premised on the position that an appropriate investigation must attract public confidence and enjoy a degree of perceived legitimacy. Public scrutiny helps to ensure the genuineness and effectiveness of the investigation and to ascertain that the investigative acts taken are necessary and reasonable; the need to protect the perceived legitimacy of the investigation by maintaining its independence and impartiality supports the same genuineness and effectiveness requirements, which ensure, in turn, the past and future oriented objectives of IHL investigations. Thus, at the end of the day, the principles underlying IHRL investigations are largely compatible with the objectives of the duty to investigate under IHL, though the precise manner of application of these principles may vary across the different legal regimes. ${ }^{109}$

\subsection{How States Maintain in Practice the Independence and Impartiality of Their Systems of Military Investigations}

As we have seen, the ECtHR has described what a proper system of investigations-applicable to all situations including armed conflict—should look like, focusing on conditions of effectiveness, independence, promptness and public scrutiny. The issue of independence (and impartiality) deserves, however, special

\footnotetext{
108 Alston Report 2010, p. 27.

109 Cf. Al Skeini, supra n. 8, para 163: "The essential purpose of such an investigation is to secure the effective implementation of the domestic laws safeguarding the right to life and, in those cases involving State agents or bodies, to ensure their accountability for deaths occurring under their responsibility."
} 
attention in the context of military investigations. True, the ECtHR has stated that any form of investigation which is subject to the same chain of command as the operation itself is illegitimate and contrary to the requirements of a proper investigation. ${ }^{110}$ However, the application of such a standard is fraught with difficulties given the autonomy traditionally afforded by many national jurisdictions to military investigation systems and the dual role of military commanders as legal subjects and law-enforcers (vis-a-vis their subordinates), a state of affairs which stands in potential tension with requirements of independence and impartiality. As a result, questions of great practical importance-such as the precise relationship between civil and military investigations, the role of civilian courts in monitoring military investigation, and the exact features of the military institutions conducting the investigation-all merit further discussion.

Given the paucity of international judicial practice that reviewed such matters and the virtual non-existence of relevant treaty standards, actual state practice may serve as a convenient point of departure for studying possible modalities for implementing the requirements of independence and impartiality to investigations of military operations. Of course, state practice may serve as a source of international law obligations or the interpretation thereof. ${ }^{111}$ Yet, identifying customary international law governing battlefield investigations requires proof that state practices derive out of conviction that international law obligates them to behave in specific ways (opinio juris). ${ }^{112}$

Since states investigate alleged violations of IHL on the basis of their own specific laws (and not international law sources), and since there exist a variety of investigative methods, Michael Schmitt concluded that state behavior cannot, in most cases, provide the basis for obligations under customary international law. We take a somewhat different position on the matter. In our view, international law does not consist only of hard and fast rules found in treaties or custom (or general principles of law); it also consists of general interpretive principles derived from treaty law, customary law or even domestic laws. Thus, even when states behave in divergent ways, common principles may be extracted from their practices and the general direction in which their practices develop may affect the manner in which existing norms are construed.

Applying this general position to the duty to investigate under IHL and IHRL we may offer the following three observations: First, to the extent that general principles of investigation law, such as effectiveness, independence, promptness and public scrutiny are reflected in state conduct they may constitute general principles of law respected by civilized nations, and represent, as such, a distinct source of international law. ${ }^{113}$ Second, the resort to criminal or disciplinary

\footnotetext{
110 Ibid, at para 167.

111 Statute of the International Court of Justice, 26 June 1945, Article 38(1)(b)(ICJ Statute): VCLT, Article 31(3)(b).

112 SS Lotus (France v Turkey), 1927 PCIJ (ser. A) No. 10.

113 ICJ Statute, Article 38(1)(c).
} 
measures to address IHL and IHRL violations lie at the border between domestic and international law. Thus, it is difficult to neatly distinguish between the domestic law and international law sources of the duty to investigate; instead, the two bodies of law appear to mutually reinforce one another. Thus, although Schmitt is right in observing that the specific details of national investigation procedures are regulated by domestic law, such laws can also be understood as the means through which states carry out their relevant international law obligations. Third, the ways in which states carry out their obligations to investigate can be indicative of developments in international law. Such developments may further underscore the emergence of general principles of international law which would further direct future practices at the national level.

\subsubsection{State Practice Suggestive of Robust Independence Standards}

\subsubsection{The Continental Approach}

One possible approach towards protecting the independence of investigations into military operations and avoiding the conflict of interests attendant to the dual role of the military as a potential law-breaker and law-enforcer, is to apply the regular rules governing domestic law violations also to violations of international law in military circumstances. ${ }^{114}$ This seems to be the approach embraced by the German legal system, where ordinary criminal procedures also control violations of the laws of war and all other military matters. ${ }^{115}$ Under this approach, which is also applicable in France and the Netherlands, ${ }^{116}$ there is no separate system of military investigations and the prosecution of crimes committed by military personnel is carried out by civilian prosecutors.

Note that even in those continental systems, such as Belgium, ${ }^{117}$ in which a designated military prosecutor for military offenses does exist, the holder of that office usually operates in complete separation from the military chain of command. Moreover, continental countries, such as Denmark or Poland, that subject military prosecutors to a certain institutional hierarchy, ensure that they are subordinate to civilian officials in the Ministry of Defense or other government institutions and not to uniformed officers. ${ }^{118}$

\footnotetext{
114 The following material regarding the Continental systems is based on the compilation by Georg Nolte, European Military Court Systems (Nolte and Krieger 2003) - a comparative review of all European military laws. The citations below are specifically to Chapter 2 "Comparison of European Military Law Systems" by Georg Nolte and Heike Krieger (ibid, at pp. 23-182).

115 Ibid, pp. 168, 169.

116 Ibid, p. 168.

117 Ibid, p. 169.

118 Ibid, p. 168.
} 


\subsubsection{Common Law Jurisdictions}

The principles of independence and impartiality are becoming also more pronounced in the context of military investigations undertaken by states following common law systems. Following several notable instances of IHL and IHRL violations, several common law countries reformed their military criminal prosecution and investigation procedures with the intention of better reflecting the principles of independence and impartiality. Perhaps the most conspicuous of these changes is the noticeable tendency to detach the investigation of military operations from the military chain of command and to prefer military police investigations to traditional investigations orchestrated by unit commanders on the ground.

\section{Canada}

Following a scandalous incident in Somalia, in which Canadian soldiers were involved in the killing of civilians, ${ }^{119}$ Canada reformed its system of military investigations and created the Canadian Forces National Investigation Service (CFNIS). All allegations of serious crimes (and all war crimes fall under that category) ${ }^{120}$ must be transferred immediately to the CFNIS which is under the direct authority of the Provost Marshal and not controlled by the commander of the unit involved. In cases where the CFNIS investigation is alleged to have been inadequate, a complaint may be filed with an independent quasi-judicial body, the Military Police Complaint Commission (MPCC), which is headed by a civilian. This body has the authority to review the investigation and issue recommendations, including the reopening of the investigation. ${ }^{121}$ The MPCC can deal with two kinds of complaints: "adequacy complaints"-brought by external bodies against an MP investigation, and "intervention complaints" brought by investigators if they feel that external intervention is hampering the investigation. ${ }^{122}$

These combined solutions, independence from the chain of command and reliance on a non-military external review commission, form the basis of the independence and impartiality of the Canadian military system of investigations. The military chain of command can no longer control the opening or halting of an investigation; nor is it responsible for the conduct of investigation. On the other hand, any external interference in the operations of the independent investigative bodies might be reviewed by a civil non-military commission.

A further aspect of the independence of the Canadian military investigation system is the role of the prosecuting authority. The prosecution of cases is handled

\footnotetext{
119 See Bercuson 2010, pp. 159-169.

120 See Canadian Forces National Investigation Service 2009.

121 National Defence Act, Article 250.

122 For general information on the MPCC see: http://www.mpcc-cppm.gc.ca/index-eng.aspx.
} 
by the Canadian Military Prosecution Service (CMPS) which is nominally part of the office of the Judge Advocate General (JAG) of the Canadian Forces but, in effect, enjoys substantial independence. This independence manifests itself in three ways. First, the director of military prosecution, which heads the office of the CMPS, is appointed by the Minister of Defense for a fixed term. Second, instructions from the JAG to the Director of Military Prosecutions must be made public; and third, there are clear guidelines as to the permissible communication between military prosecutors and legal advisors assigned to military units. ${ }^{123}$

\section{Australia}

The Australian system has also undergone several changes in recent years, especially following a report issued by the Australian Parliament in 2005 which criticized the adequacy of the military system of investigations. ${ }^{124}$ Since further reforms are currently in the legislative pipeline, the system is still in flux. Nevertheless, following a recent decision of the Australian Supreme Court, the essential contours of the new system have already emerged and parts of it have already been applied to the Australian Defence Forces (ADF).

Perhaps the most noticeable characteristic of the Australian system of investigation is its heavy reliance on monitoring bodies which are essentially civilian or directly controlled by civilian authorities. The primary investigative authority is the ADF Investigative Service which is responsible for investigating all serious crimes (including all war crimes). ${ }^{125}$ This service is independent from the regular military chain of command and is under the command of the Australian Provost Marshal, who is appointed by the Chief of Staff. ADF legal services that carry responsibility for the prosecution of crimes are under the command of a civilian prosecutor who heads the service. In addition, the organizational command of the military disciplinary system is in the hands of the Judge Advocate General-a civilian Federal judge who is appointed to the post for a term of 7 years. Finally, the Military Inspector General (another official operating outside the military chain of command) has authority to review the operation of the military system.

It is important to note that recent war crimes legislation adopted in Australia, following its accession to the ICC, might allow for the civil prosecution of certain

${ }^{123}$ Director of Military Prosecutions, Policy Directive no. 009/00: Communications with Legal Advisors (updated on March 18, 2009). The role of this directive is:

To permit those communication that provide "the required degree of coordination but do not impact on the independence of the Prosecutor and the exercise of prosecutorial discretion." Ibid, Article 2. Available at: http://www.forces.gc.ca/jag/publications/cmps-scpm/policy-politiques009-eng.asp.

124 Foreign Affairs, Defence and Trade References Committee, The Effectiveness of Australia's Military Justice System (June, 2005).

125 Department of Defence Instructions (supra n. 72). 
violations of IHL. ${ }^{126}$ Although no prosecutions have yet been carried out in accordance with the new war crimes legislation, this development clearly increases the potential for civilian involvement in the investigation of military operations.

\section{United Kingdom}

The United Kingdom's system is similar to the Australian in several respects. First, the Special Investigative Service is independent of the regular military chain of command and has independent authority to initiate military investigation. Moreover, although many investigations are initiated on the authority of the commanding officer, holders of that office no longer possess the authority to halt investigations. In addition, it is notable that the prosecuting service of the UK is headed by a civilian.

There are, however, several additional and unique features of the UK investigative procedure which merit a short discussion. First, UK courts have been willing in recent years to embroil themselves in assessing the adequacy of military investigations. In recent years the courts have issued opinions regarding the $A l$ Skeini case, ${ }^{127}$ Al Jedda Case, ${ }^{128}$ the Baha Mousa inquiry (which originated from the Al Skeini case $)^{129}$ and others. This willingness on the part of UK courts to review military investigations is an additional form of review which contributes to the independence of the military system.

Second, one could mention the ability of individual cabinet members and of the cabinet as a whole to form independent investigation bodies. Several such investigations have been initiated in the UK in recent years, the most notable of which being the Iraq Historic Allegation Team (IHAT) established with a mandate to "investigate allegations of abuse of Iraqi citizens by British Service personnel." ${ }^{130}$ Interestingly enough, the Court of Appeal recently struck down the IHAT investigation mechanism, declaring it as not independent because some members of the IHAT team were also members of the Royal Military Police (RMP). The RMP, the Court emphasized, was potentially a subject of the investigation and hence the investigation could not be said to be independent. ${ }^{131}$

The examples cited above suggest a trend in the practices of three important common law systems of military investigations. This trend aligns these systems

\footnotetext{
126 International Criminal Court (Consequential Amendments) Act 2002 (Austl.).

127 Al Skeini v. Secretary of State for Defence [2007] UKHL 26.

${ }^{128} R$ (on the application of Al-Jedda) (FC) v. Secretary of State for Defence [2007] UKHL 58, 12 December 2007).

129 http://www.bahamousainquiry.org.

130 http://www.mod.uk/DefenceInternet/DefenceNews/DefencePolicyAndBusiness/ IraqHistoricAllegationsTeamStartsWork.htm.

131 Mousa v. Secretary of State [2011] EWCA Civ 1334.
} 
more closely to the continental way of thinking about the independence of investigations of compliance by the military with its IHL and IHRL obligations and suggest increasing support in state practice for the need to ensure the independence of military investigations through removing investigative bodies from the chain of command, involving civilians in the administration and monitoring of military investigations, and subjecting investigations to civilian review institutions, such as courts and commissions of inquiry.

In the Mousa decision, cited above, the Court of Appeal explained the reasons for this shift in emphasis:

One of the essential functions of independence is to ensure public confidence and, in this context, perception is important. ${ }^{132}$

Thus, independence is an important part of maintaining public trust in military investigation and persons who conduct an investigation into military conduct should be as detached as possible from any institution which could be viewed as responsible for the investigated violation. While such practices do not constitute in themselves an international custom, they do suggest a movement in international practice towards more robust standards of independence and impartiality in military investigations.

\subsubsection{State Practice Standing in Tension with the Principle of Independence}

The above analysis of the investigative practices adopted in various countries is not intended to suggest that the procedures used in each reviewed country are perfectly compatible with the principles governing proper investigations. To the contrary, certain specific aspects of military investigation employed by some armed forces appear to us to be inadequate when juxtaposed against the principles of independence and impartiality.

\subsubsection{Operational De-Briefing}

Operational de-briefings are investigations conducted by the same unit implicated in the alleged violated through investigators who belong to the same chain of command as the suspects. These procedures are not carried out with the intention of initiating criminal prosecution; rather, they are military tools for assessing the quality of operational activity and for lesson learning. While no doubt useful from

132 Ibid, at para 35. 
a military point of view, operational debriefings may pose a significant problem to the effectiveness and legitimacy of criminal investigation since they are conducted by the same service members that may have been responsible for the violation in question (as direct perpetrators, accomplices or incurring command responsibility). Hence, they cannot satisfy the requirements of independence and impartiality. 133

It is not surprising that some militaries have adopted procedures designed to limit the use of operational de-briefings in serious cases and to minimize their harmful effects when used. Hence, some military laws provide that criminal investigations would take precedence over operational debriefings, ${ }^{134}$ and some even go further and require their suspension in cases suitable for a criminal investigation. ${ }^{135}$

\subsubsection{Limited Exercise of Jurisdiction by Civilian Courts}

Another problem related to the independence of military investigations is the tendency of civilian courts not to assert their jurisdiction over the conduct of such investigations. This reluctance is sometimes explained by reference to the view that military investigations are a matter of policy and, as a result, are situated in an area of law over which judicial monitoring should be minimal. ${ }^{136}$ This is reinforced by a set of legal doctrines limiting the involvement of domestic courts in reviewing military operations conducted outside the relevant state's territory. ${ }^{137}$ The upshot of this reluctance to supervise military investigations is that militaries have a smaller incentive to conform their practices to high standards of investigative conduct (including, independence and impartiality); furthermore, the absence of a credible threat of external judicial review makes it more difficult for military investigators to resist organizational pressures and conflicts.

133 Operational debriefings may suffer from other relevant quality deficiencies: First, they are performed by members of the military who are not professional investigators. This adversely affects the quality of the investigation, especially if the scene of the crime is not adequately preserved. Second, the process also allows suspects to coordinate their testimony and to find out what evidence was gathered. Hence, it might be said that the continued use of debriefing when there exists a prime facie need for a full criminal investigation is problematic, and might cause a violations of the duty to conduct a proper investigation.

134 See e.g., Department of Defence Directive 2311.01E, May 9, 2006, section 4.5 (US).

135 See e.g., Defence Instructions (General) Admin 67-2, 7 Aug. 2007, Annex C (Austl.).

136 For an analysis of the different views regarding National Court's involvement in national security matters see: Benvenisti 2008, p. 241.

137 See e.g., Banković v. Belgium, Judgment of 12 Dec. 2001, no.52207/99 ECHR 2001, para 59 (ECHR does not apply to extra-territorial air attacks). These limits were eroded, but revoked in Issa v. Turkey, supra n.8; Al Skeini v. UK, supra n.8. 


\subsubsection{The Recent Israeli Debate Over the Independence and Impartiality of Its System of Military Investigations}

The debate in Israel concerning the independence and impartiality of its military investigations system, generated by the follow-up reports of the HRC to the Goldstone Report and by the Turkel Committee (a public committee formed after the 2010 Gaza Flotilla incident), are valuable to the present article as they demonstrate an attempt by a legal system to reevaluate the independence and impartiality of its responses to alleged IHL and IHRL violations perpetrated by its armed forces on the battlefield. At the heart of the debate currently taking place in Israel lies the extensive use of operational debriefings, the delicate position of IDF military lawyers and the limited civilian control over military investigations. All of these aspects of the IDF military investigation system appear to be out of step with developments taking place in some other military and stand in tension with the requirements of independence and impartiality of military investigations.

\subsubsection{Operational Debriefing}

Israel's experience with using operational debriefings has changed over the years. Since 2001 operational debriefings have become, in effect, part of the investigation procedures applied by the IDF; such fact-finding inquiries have been routinely opened by the military following military operations resulting in one or more civilian deaths (in the absence of evidence showing the perpetration of a crime). Thus, such procedures serve as de facto substitutes for criminal investigations (up until 2000 - the year in which violent hostilities broke between Israelis and Palestinians - criminal investigations were the automatic reaction to civilian deaths). In his testimony before the Turkel commission, examining Israel's military investigation system, the IDF Military Attorney General (MAG) stated that information disclosed by the operational de-briefings may lead him to open a fullfledged criminal investigation. ${ }^{138}$

We are of the view that operational debriefings - to the extent that they are conducted by officers of the same unit involved in the allegedly unlawful military operation-fail to meet international standards of independence and impartiality required from proper investigations. While there is no prohibition against conducting lessons-learnt exercises in parallel to proper investigations (which should be effective, independent, impartial, prompt and subject to some form of public scrutiny), more attention must be given to the potential conflict between the needs of the investigation and the conduct of operational debriefings. The latter should be prioritized in our view only in exceptional cases where overriding concerns of

138 The information in this part is based on the submissions of the IDF MAG to the Turkel Commission (on file with authors). 
military necessity require the postponement of independent and impartial investigations.

\subsubsection{The Delicate Position of IDF Military Lawyers}

Although the IDF MAG, the most senior lawyer in the Israeli military, is nominally independent in his decisions, he is appointed jointly by the Chief of the IDF General Staff (CGS) and the Minister of Defense. In addition, his term of office is not defined and recent MAG's have been promoted (to the rank of Major General) during their term of office. Naturally, this raises some concerns regarding the independence of their office when conducting investigations that may implicate the highest ranks in the military and government.

An additional problem afflicting the Israel system of military investigations involves the dual capacity of the MAG as both the chief legal advisor of the military and the head of military prosecutions (and in effect also the head of military investigations). ${ }^{139}$ This highly centralized system creates the appearance of partiality: the MAG is responsible both for giving operational advice with respect to military operations and for conducting investigations which sometimes involve operations which followed the same advice. ${ }^{140}$

\subsubsection{Limited Civilian Controls over IDF Military Investigations}

The aforementioned independence and impartiality shortcomings may be somewhat offset by the involvement of civilian officials- the office of the State Attorney General and the Israeli Supreme Court-in important decisions regarding investigations and prosecutions. Still, it is questionable whether the Attorney General's office possesses sufficient expertise in international law in order to effectively monitor the MAG and his subordinates. As for the Supreme Court, it has shown interest in almost all aspects of national security ${ }^{141}$ including military investigations. However, the main thrust of the court's jurisprudence has been in

\footnotetext{
139 In his written and oral testimonies before the Turkel Commission, the MAG emphasized the fact that he is involved personally, or through subordinates, in all important MP investigations through the system of "operational investigative unit" at the MAG's headquarters.

${ }^{140}$ Criticism on the multiple roles of the MAG has been voiced by the UN Report 2010, at para 53 ("In spite of the structural guarantees of independence built into the military justice system, the dual responsibilities of the MAG, in the specific context of these investigations, raise concerns of a lack of impartiality. The MAG is legal adviser to the Chief of Staff and other military authorities. Yet, at the same time, he is the supervisor of disciplinary law in the military. Although the combination of the advisory and supervisory functions in one office does not automatically lead to a conflict of interest or a lack of impartiality, the situation is complicated in the present case by the fact that many of the allegations of serious violations of IHL and IHRL in the FFM report directly link to the advice he provided").

141 Cohen and Cohen 2011.
} 
support of an institutional solution that would not require a case-by-case review by the Supreme Court of military investigations but, rather, be based on other forms of independent inquiry. Up until now, only a few independent mechanisms of inquiry have been established by the Israeli government-mostly on an ad hoc basis_-and with limited jurisdiction.

\subsubsection{Interim Conclusions}

The survey of law and practice above points at the emergence of legal standards governing proper investigations into military operations in which IHL and/or IHRL norms may have been violated. Such principles include requirements of effectiveness, genuineness, promptness, independence and impartiality, and public scrutiny. The application of these principles may be subject, however, to specific IHL provisions including military necessity interests and to battlefield conditions. But even here, we have identified increased willingness by some military legal systems to review existing procedures in order to minimize tensions between traditional military practices and the principles of proper investigation. Such a review has led to increased resort to investigation conducted by individuals and institutions located outside the chain of command, a growing involvement of civilians in the process and stronger mechanisms of judicial review. Even a country such as Israel that has not embraced fully such reforms is at present in the process of considering them.

\subsection{Operationalizing a Broad Duty to Investigate: Reconciling Tensions Between Different Investigation Tracks}

In the Al Skeini case, the ECtHR pointed out that:

Civil proceedings, which are undertaken on the initiative of the next-of-kin, not the
authorities, and which do not involve the identification or punishment of any alleged
perpetrator, cannot be taken into account in the assessment of the State's compliance with
its procedural obligations under Article 2 of the Convention. Moreover, the procedural
obligation of the State under Article 2 cannot be satisfied merely by awarding damages. ${ }^{142}$

This dicta reflects a strong preference for criminal law as the main vehicle for addressing serious violations of IHL and IHRL. Still, once it is accepted that a duty to investigate arises beyond the grave breaches regime covering less serious violations of IHL and IHRL, a more nuanced position on the role of criminal investigation may be considered, Furthermore, modalities for ensuring the application of the principles of proper investigation across the board of investigation mechanisms need to be developed.

${ }^{142}$ Al Skeini v. UK, supra n.8. 
In this part of the paper we wish to stress that in some specific cases, criminal investigation does not constitute the sole avenue open to states wishing to satisfy the duty to investigate violations of IHL and IHRL. In so doing, we shall take issue with the position that only criminal investigations satisfy the conditions of independence, impartiality, effectiveness, promptness and public scrutiny.

In actuality, many, if not most, criminal investigations do not end in prosecution or conviction - an outcome which may be less indicative of institutional sloppiness or bad faith and more to do with the inherent difficulties of establishing individual guilt in battlefield conditions. Under these circumstances, one may seriously question whether criminal investigations are the most effective investigative technique available to militaries. ${ }^{143}$ In fact, the experience of states such as the UK and Israel suggests that non-criminal investigations, which satisfy the requirements of international law, are sometimes more effective than criminal ones.

In order to understand when criminal investigations may represent a suboptimal response to certain IHL and IHRL violations, it may be useful to identify some of the problems associated with criminal investigations. We shall then discuss the pros and cons of a few alternative mechanisms that may better fulfill, under certain circumstances, the broad duty to investigate.

\subsubsection{Problems with the Criminal Investigation of IHL and IHRL Violations}

Criminal investigations of IHL and IHRL violations confront enormous obstacles in all military conflicts, regardless of their precise nature and intensity. Such obstacles may render suboptimal a criminal response to certain violations occurring under battlefield conditions.

\subsubsection{Clarity and Certainty of IHL}

One problem confronting investigators and prosecutors endeavoring to apply criminal law to IHL violations involves the application of the principle of legality in situations of legal uncertainty. Although historically, the Laws of Armed

143 According to the information discussed in the Al Skeini, supra n.8-out of 200 investigation opened by the SIB regarding UK operations in Iraq, relating to suspected law violations leading to a death of civilians, only four were transferred to prosecutors with a recommendation to indict. Of these three were indeed brought to trial, in no case was there a conviction for murder or manslaughter. In Israel the situation is quite similar. Of almost 50 criminal investigations opened by The MAG Department of the IDF after "Operation Cast Lead" in Gaza (Dec. 2008-Jan. 2009), only a few were brought to trial, and conviction were handed in two (2) cases-one of which deal with looting, and the other with endangering a civilian. See: Ministry of Foreign Affairs 2010. 
Conflict (LOAC) were associated with clear rules (reflective to a considerable degree with the combatants' self-interest), ${ }^{144}$ the move from rules to standards ${ }^{145}$ reduced legal certainty, and thus created serious problems for criminal enforcement - a process which assumes the existence of pre-existing and well defined legal prohibitions. Perhaps the best known example is the proportionality principle, which leaves unanswered many questions that can only be resolved, if at all, at the law-application stage. ${ }^{146}$ As the special report to the prosecutor of ICTY regarding the NATO campaign in Yugoslavia pointed out when explaining the recommendation not to initiate criminal proceedings against NATO service members for excessive collateral damage: "[i]t is much easier to formulate the principle of proportionality in general terms than it is to apply it to a particular set of circumstances." 147

Without going into further detail, it is quite clear that this apparent shift in IHL complicated the possibility for establishing beyond reasonable doubt the criminal nature of the actus reus and mens rea of military operations leading to what is often unforeseen collateral damage. Such proof of guilt is rendered particularly difficult to attain when battlefield conditions hinder evidence gathering, and in situations where the investigated incidents involve the activities of groups of individuals, whose distinct contribution to the alleged violation is hard to isolate. It is therefore not surprising that international criminal courts tend to avoid dealing with the application of the principle of proportionality. ${ }^{148}$ Arguably, the criminal enforcement under battlefield conditions of many IHRL norms, which also reflect equilibrium between competing values and interests subject to a proportionality analysis, raises similar challenges.

\subsubsection{Legal Advice and Criminal Prosecutions}

Another important problem associated with the use criminal law as a tool for suppressing violations of IHL is, perhaps paradoxically, the increased tendency of many militaries to resort to operational legal advice. The obligation to employ legal advisors was first mentioned in the First Additional Protocol to the Geneva Conventions. Article 82 to the Protocol states that:

The High Contracting Parties at all times, and the Parties to the conflict in time of armed conflict, shall ensure that legal advisers are available, when necessary, to advise military commanders at the appropriate level on the application of the Conventions and this Protocol and on the appropriate instruction to be given to the armed forces on this subject. ${ }^{149}$

\footnotetext{
144 Jochnik and Normand 1994.

145 Cohen 2008.

146 For a general survey of the proportionality principle in jus in bello see Gardam 1993, p. 391.

147 NATO Bombing Review Committee Report 2000.

148 Cohen 2009, p. 35.

149 AP-I, Article 82.
} 
According to the Commentary to the Protocol, legal advisors should be available at the level of the division, or even of the brigade, if the brigade operates independently. ${ }^{150}$ Over time, many militaries developed operational legal advisory services for their armed forces meeting to a large extent the standards identified in the Protocol and its Commentary. ${ }^{151}$

There are several good reasons why armed forces should seek legal advice. Most obviously, the extensive reliance on legal advisors supports a culture of legality and internalizes international law norms into the operations of the armed forces. ${ }^{152}$ Still, it might prove to be very problematic to prosecute commanders and other military personnel who follow the legal advice that they receive, as basic principles of criminal law render it difficult to convict a person who followed the advice of his or her lawyers. Although legal advice cannot serve as a defense in circumstances where the violation of law was clear in nature, ${ }^{153}$ the increased ambiguity of modern IHL and IHRL norms renders it increasingly unlikely that clear violations would be committed in a manner exposing the service-member in question or his or her lawyer to criminal proceedings. Hence, operational legal advice may shield, in effect, military service members acting on such advice from criminal responsibility.

\subsubsection{Reluctance to Prosecute}

Another problem associated with criminal prosecutions for violations of IHL and IHRL by the military is the reluctance of states to prosecute persons who acted in their name, often pursuant to superior orders. It is important in this regard to draw a bright line separating violations of international law which are also violations of internal military codes and order from violations of international law committed as part of official military policy. ${ }^{154}$ While militaries occasionally prosecute lowranked soldiers for unauthorized violations, prosecutions of high-ranked officers responsible for promulgating allegedly criminal policies or orders (or of lowranked soldiers that followed them) are much less common. It follows that the main added value of international criminal law is to force the state to do precisely

\footnotetext{
150 This conforms to the current American military doctrine see Army Field Manual 27-100 (1991) 1-9, g. (pp. 5, 6).

151 Military manuals which contain such obligations include those of Australia, Belgium, Cameroon, Canada, France, Germany, Hungary, Italy, Netherlands, Nigeria, Russia, Spain, Sweden and the US. Many of the states which have not joined the additional protocol have also declared that they possess this service-e.g., India, Sri Lanka, Turkey, and Israel. In fact, the ICRC Study on Customary International had declared the existence of the legal advisors service as customary in nature. Henckaerts and Doswald-Beck 2005, p. 500.

152 Cohen 2011.

153 Bowker 2005, p. 183.

154 Cohen 2005; Ben Ari and Cohen 2010.
} 
that which is most reluctnat to do-to prosecute high level officers for devising and implementing official state policy that runs contrary to international law.

The tendency of the state not to prosecute for serious violations of IHL and IHRL is facilitated, in part, by the above-mentioned lack of enthusiasm by domestic courts to involve themselves in matters of national security. Hence, both military and civilian legal institutions might under-enforce IHL and IHLR against perpetrators of 'official' violations. Note that even when military trials do take place, they often result in acquittals or the imposition of relatively modest levels of punishment for crimes committed by one's own soldiers against enemy soldiers or civilians. $^{155}$

As much as we object to this sad state of affairs, this situation must be taken into account when considering the entire gamut of responses to IHL and IHRL violations. To be sure, we are not claiming that the criminal venue is an inadequate response to war crimes or other serious violations of international law. Domestic criminal prosecutions, even on a small scale and with relatively light punishments, may have an important symbolic effect and generate real deterrence. ${ }^{156}$ Still, it is questionable whether an exclusive focus on criminal law is always an effective means for enforcing IHL and IHRL. Instead, we propose in the next segment that a greater role in the enforcement of IHL and IHRL should be assigned to independent commissions of inquiry.

155 There were only three criminal cases in the UK regarding the operations in Iraq, and in all cases the convictions did not concern manslaughter or murder, but lesser offences (supra note 143). In Israel, military courts convicted Israeli soldiers during the second intifada of relatively minor offences, such as "behavior unbecoming." See e.g., Ben Naftali and Zamir 2009. In the aftermath of the Abu Ghraib prison scandal, 11 US soldiers were convicted on charges of abuse of prisoners and negligent performance of duty. No one was convicted of murder or manslaughter (although several Iraqi prisoners died while in custody). No officer was convicted in charges relating to the actual abuse. The highest rank of a soldier convicted in relations to the actual abuse was a Staff Sergeant. In Canada a similar pattern took place: in the Belet Huen incident in Somalia, out of the 9 persons charged, four were officers. All were either acquitted of all charges (two cases) or convicted for negligent performance of duty. Three soldiers at the ranks of Private and Sergeant were convicted of second degree murder, and sentenced to up to 5 years in jail, of which they served a maximum of 1 year.

156 For example, the legal proceedings that took place in the US following the My Lai massacre in Vietnam produced a lasting effect on the US military despite the relatively minor results of the trials,. See generally Lippman 1993, Similarly, an Israeli criminal conviction in the case of Malinki (Kaffar Kasem case, 1958), instilled in the IDF the principle of the duty to disobey a blatantly unlawful order, notwithstanding the light punishment imposed. Military Court case no. 3/57(central command) Military Prosecutor v. Malinki, District Court Case 17, 90 (p. 21-3-214) (1958). 


\subsubsection{The Use of Non-Criminal Accountability Mechanisms: Independent Commissions}

One possible non-criminal response to allegations or suspicions of violations of IHL and IHLR can be found in the form of commissions of inquiry. Such commissions are composed of independent and impartial reviewers and are authorized to ascertain the events that led to the alleged violation and issue policy and other recommendations. Such recommendations may lead to the revision of military practices and can include certain sanctions (such as demotion or dismissal of officers) or remedies (such as compensation to victims). ${ }^{157}$ In certain cases, the factual record of commissions of inquiry may serve as the basis for follow-up legal proceedings including criminal prosecution of suspected criminals. Arguably, some commissions-especially composed of experts in military law and doctrine-are better placed than courts in reviewing systemic problems involving IHL violations and in facilitating policy reforms. ${ }^{158}$

Recent examples of commission of inquiry include the 'Somalia Commission' appointed by the Government of Canada in order to investigate the misconduct of members of the Canadian Airborne Regiment at Belet Huen in south central Somalia in $1993^{159}$; the enquiry conducted by the Dutch Institute for War Documentation into the responsibility of Netherlands forces for the Srebrenica massacre of 1995 in Bosnia and Herzegovina ${ }^{160}$; and the Chilcot Inquiry established by the British government to consider the UK's involvement in Iraq from mid2001 to July 2009. ${ }^{161}$ In Israel, the Supreme Court recommended that an independent commission examine allegations of illegality concerning targeted killing operations $^{162}$ (one ad hoc commission reviewed the legality of one specific targeted killing attack from 2002 resulting in extensive collateral damage $)^{163}$; in

\footnotetext{
157 Ronen 2009.

158 In a recent case the Israeli Supreme Court stressed this point. While rejecting a petition to open criminal investigation regarding Israeli operations in the Gaza strip in 2004, it noted that the Israeli system provides for alternative methods of investigation where, as in that case, criminal investigations are inappropriate. See HCJ 3292/07 Adallah v. Attorney General (unpublished decision of 8 December 2011)("The petitioners before us ask for a conduct of a criminal investigation. In the circumstances before us, the tool of criminal investigation is inappropriate and does not properly respond to the problematic issues raised in this case, first and foremost for reasons based on the character of criminal law") (unofficial translation).

159 The Somalia Commission of Inquiry 1997.

$160 \mathrm{http}: / / \mathrm{www}$. srebrenica-project.com/index.php?option=com_content $\&$ view=article \&id=140:

niod-report\&catid=12:2009-01-25-02-01-02.

$161 \mathrm{http}: / /$ www.iraqinquiry.org.uk/about.aspx

162 The Public Committee Against Torture in Israel v. Gov't of Israel, supra n.44.
}

163 On July 22, 2002 a targeted killing operation took place against Saleh Shehadeh, a leading Hamas operative. In addition to Shehadeh himself, his wife and daughter, 14 other people were killed. Following a recommendation of the Israeli Supreme Court, an independent commission was formed to investigate possible violations of law in the incident. The commission, headed by 
addition, a committee was established in 2010 to review the legality of IDF operations against the Gaza flotilla (the Turkel Commission). ${ }^{164}$ The US has also resorted to commissions of inquiry to review the propriety of certain military or intelligence operations. Thus, a commission was established in the aftermath of the Abu Ghraib prison scandal ${ }^{165}$; another commission led by a former Secretary of Defense reviewed the entire detention operations of the $\mathrm{US}^{166}$; and yet another committee reviewed the responsibility of lawyers who authorized aggressive investigation techniques. ${ }^{167}$

Although commissions of inquiry may meet the general requirements of a proper investigation, this form of response nevertheless remains open to several objections. One key concern is that governments may manipulate the commission's mandate or composition in order to deflect responsibility or avoid it altogether. Hence, a critical assessment of the effectiveness and independence of each commission is warranted.

One possible fix to the threat of governmental manipulation of the composition of commissions of inquiry may be found in entrusting their investigative tasks in the hands of permanent investigative bodies that would operate beside, or as part of, national humanitarian law commissions ${ }^{168}$ or human rights institutions. ${ }^{169}$ The structure of such permanent Humanitarian Law Commissions (HLC) should conform, as much as possible, to the Paris Principles governing the operation of national human rights institutions, ${ }^{170}$ which call inter alia for independence, adequate resources and representation of civil society.

Note that the permanency of HLCs addresses not only several independence and impartiality concerns, but also some effectiveness concerns: over time,

\section{(Footnote 163 continued)}

retired Supreme Court justice Tova Strassberg Cohen, the report concluded that there were no criminal violations of IHL in the incident, but made several recommendations as for the future use of targeted killings-Strassberg-Cohen Commission 2011.

164 The Turkel Commission 2011.

165 Article 15-6 investigation of the 800th Military Police Brigade (Tagoba Report) June 2004, available at: http://news.findlaw.com/hdocs/docs/iraq/tagubarpt.html\#ThR1.13.

166 Schlesinger Report 2004.

167 The Office of Professional Responsibility report 2009.

168 National Humanitarian Law Committees' (NHLC's) now exist in 93 countries. Their functions vary from country to country, but frequently extend to: monitoring decisions taken by national security agencies; coordinating between different government agencies regarding the implementation of IHL; disseminating IHL material; proposing legislation that conforms with IHL; and reviewing international treaties and developments. For a description of NHLC's see: http://www.icrc.org/eng/war-and-law/ihl-domestic-law/natrional-committees/index.jsp.

169 National Human Rights Institutions (NHRIs) or Commissions, currently operate in more than a hundred countries. Their precise powers and functions vary from one case to another. In some places, they adjudicate complaints against the executive and its various agencies regarding violations of human rights, including at times violations committed by the military (e.g., as in the case of Uganda). Livingstone 1999, Lee Wetzel 2007.

170 G.A Res. 48/134, December 20, 1993. 
permanent investigative bodies can accumulate considerable expertise in handling problems relating to IHL and IHRL compliance in military operations. In addition, the establishment of a permanent HLC may signal greater commitment on the part of the state in question to international law ${ }^{171}$ — a signal which may entail reputational dividends, as well as decrease the prospects of intervention by international judicial bodies in that state's military investigation system.

If established, an HLC could monitor the propriety of criminal or disciplinary investigations conducted by the military; but, more importantly, it could also engage in policy review-i.e., reviewing ex post whether a specific policy or operation was conducted in accordance with international law and issuing recommendations for future military actions. Such recommendations may clarify for the military some of the more complex norms it is required to implement. HLC reports may also lead to the award of compensation by law or ex gratia payments to individuals harmed in military operations. ${ }^{172}$ In order to fulfill these functions, HLCs need to be invested with genuine investigative powers (e.g., the power to require witnesses to appear before them, to receive any document it seeks, and to gather information in situs).

One important advantage that may appertain to a permanent HLC concerns the aforementioned tension between the military need for secrecy and the principle of public scrutiny. By entrusting an independent commission with powers of monitoring and investigating military operations and inquiries, some degree of accountability and transparency is maintained; at the same time, the commission would be expected to protect the confidentiality of sensitive intelligence and testimonies. So, unlike courts, permanent HLCs may deal with systemic issues-not just individual cases-and may do so in a more flexible and, at times, more confidential manner. Still, courts ought to retain the power to monitor the propriety of the commissions and their operations. ${ }^{173}$

\subsection{Conclusion}

In this article we reviewed the international duty upon states to investigate alleged violations of international law occurring during armed conflicts. We found that international standards for the conduct of a proper investigation in international law require a genuine process that is effective, independent and impartial, prompt and subject to public scrutiny. We also pointed out that the current trend in

171 For the importance of signaling to the effectiveness of international law obligations see: Guzman 2008.

172 For a general call for compensation in all collateral damage cases, see Ronen 2009.

173 The Ali Mousa decision issued by the UK High Court of Justice in December 2010, exercises this precise function with relation to the IHAT. In its decision, the court reviewed the independence and impartiality of the IHAT, which it declared to be sufficiently independent. Ali Zaki Mousa v. Secretary of Defence [2010] EWHC 3304 (admin). 
national investigation practices is towards a greater degree of independence and civilian control over military investigation bodies.

In addition, we are of the view that military investigation systems should not maintain an exclusive focus on criminal investigations of grave breaches of IHL. This is because international law requires states to suppress all breaches of IHL and IHRL. Furthermore, suppression of violations through criminal investigation and prosecution is not always the most effective response to alleged violations. Instead, international law sources as well as state practice support resort to other possibilities including permanent commissions of inquiry, which can, if built properly, satisfy under certain circumstances international law's requirements for a proper investigation.

\section{References}

Abresch W (2005) A Human Rights Law of Internal Armed Conflicts: The European Court of Human Rights in Chechnya. Eur J Int Law 16:741

Alston Report (2010) Report of the special rapporteur on extrajudicial, summary or arbitrary executions, Philip Alston Addendum: study on targeted killings, UN Doc A/HRC/14/24/ Add.6 (28 May 2010)

Ben Ari E, Cohen A (2010) (unpublished paper, on file with authors) The application of International Humanitarian Law by the Israel Defence Forces: a legal and organizational analysis

Ben Naftali O (2011) Introduction International Humanitarian Law and International Human Rights Law-Pas De Deux. In: Ben-Naftali O (ed) International Humanitarian Law and International Human Rights Law. Oxford University Press, Oxford

Ben-Naftali O, Shany Y (2004) Living in denial: the application of human rights in the occupied territories. Israel Law Rev 37:17

Ben-Naftali O, Zamir N (2009) Whose conduct unbecoming? The shooting of a handcuffed blindfolded demonstrator. J Int Crim Justice 7:155

Benvenisti E (2008) Reclaiming democracy: the strategic uses of foreign and international law by national courts. Am J Int Law 102:241

Bercuson DJ (2010) Up from the ashes: the re-professionalization of the Canadian forces after the 'Somalia Affair'. In: Cohen Stuart A (ed) The new citizen armies. Routledge, London

Bill B, Marsh J (eds) (2010) International and Operational Law Department. Operational Law Handbook. Available at http://www.loc.gov/rr/frd/Military_Law/pdf/operational-lawhandbook_2010.pdf

Bowker DW (2005) Unwise counsel: the war on terrorism and the criminal mistreatment of detainees in U.S. custody. In: Greenberg KJ (ed) The torture debate in America. Cambridge University Press, Cambridge

Byron C (2007) A blurring of the boundaries: the application of International Humanitarian Law by human rights bodies. Va J Int Law 47:839

Canadian Forces National Investigation Service (2009) Annual report (Novemb 2009). Available at http://www.vcds.forces.gc.ca/cfpm-gpfc/cfp-ggp/nis-sne/ar-ra/2008/doc/nisar-snera-2008eng.pdf

Cohen A (2005) Administering the territories: an inquiry into the application of IHL in the territories. Israel Law Rev 38(3):24

Cohen A (2008) Rules and standards in the application of International Humanitarian Law. Israel Law Rev 41:41 
Cohen A (2009) The principle of proportionality in the context of operation cast lead: institutional perspectives. Rutgers Law Rec 35:23

Cohen A (2011) Legal operational advice in the IDF. Conn J Int Law 26:367

Cohen A, Cohen SA (2011) Israel's National Security Law: political dynamics and historical development. Routledge, London

Dickinson LA (2010) Military lawyers on the battlefield: an empirical account of International Law compliance. Am J Int Law 104:1

Danner MA (2003) Enhancing the legitimacy and accountability of prosecutorial discretion at the International Criminal Court. Am J Int Law 97:510

Franck TM (1990) The power of legitimacy among nations. Oxford University Press, Oxford

Gardam JG (1993) Proportionality and force in International Law. Am J Int Law 87:391

Goldstone Report (2009) UN fact-finding mission on the Gaza conflict (25 Sept 2009). UN Doc. $\mathrm{A} / \mathrm{HRC} / 12 / 48$

Guzman AT (2008) How International Law works? A rational choice theory. Oxford University Press, Oxford

Henckaerts J-M, Doswald-Beck L (2005) Customary International Humanitarian Law (vol 1). Cambridge University Press, Cambridge

Holmes JT (1999) The principle of complementarity. In: Lee RS (ed) The International Criminal Court: the making of the Rome Statute. Kluwer International, The Hague

ICRC (2007) International Humanitarian Law and the challenges of contemporary armed conflicts. Int Rev ICRC 89:719

Israel Law Review (2007) Special issue: the parallel applicability of International Humanitarian Law and International Human Rights Law. Israel Law Rev 40:307

Jochnick C, Normand R (1994) The legitimization of violence: a critical history of the laws of war. Harv Int Law J 35:49

Koivurova T (2008) Due diligence. In: Rüdiger W (ed) (online edn.) Max Planck Encyclopedia of Public International Law. Oxford University Press, Oxford

Lee Wetzel A (2007) Post-conflict national human rights institutions: emerging models from Northern Ireland and Bosnia \& Herzegovina. Columbia J Eur Law 13:427

Lippman M (1993) The My Lai massacres and the Vietnam war. S-Diego Justice J 1:295

Livingstone S (1999) The Northern Ireland Human Rights Commission. Fordham Int Law J $22: 1465$

Lubell N (2010) Extraterritorial use of force against non-state actors. Oxford University Press, Oxford

Mackenzie R et al (eds) (2010) Manual on international courts and tribunals. Oxford University Press, Oxford

Milanovic M (2011) Extraterritorial application of human rights treaties: law, principles and policy. Oxford University Press, Oxford

Ministry of Foreign Affairs (2010) Second report on the status of investigations of alleged violations of international law during "Operation Cast Lead" undertaken by the Israel Defense Forces (July 2010). Available at http://www.mfa.gov.il/NR/rdonlyres/1483B2967439-4217-933C653CD19CE859/0/GazaUpdateJuly2010.pdf

NATO Bombing Review Committee (2000) Final report to the prosecutor by the committee established to review the NATO bombing campaign against the Federal Republic of Yugoslavia. ILM 39:1257

Newton M (2007) Modern military necessity: the role and relevance of military lawyers. Roger Williams Univ Law Rev 12:877

Nolte G, Krieger H (2003) Comparison of European military law systems. In: Nolte G (ed) European military court system. De Gruyter Recht, Berlin

Office of Professional Responsibility (2009) Investigation into the office of legal counsel's memoranda concerning issues related to the Central Intelligence Agency's use of "enhanced interrogations techniques" on suspected terrorists (29 July 2009). Available at http:// judiciary.house.gov/issues/issues_OPRReport.html 
Pictet JS (ed) (1958) Commentary on the IV Geneva Convention relative to the protection of civilian persons in time of war of 12 August 1949. International Committee of the Red Cross, Geneva

Prud'homme N (2007) Lex Specialis: oversimplifying a more complex and multifaceted relationship? Israel Law Rev 40:356

Ronen Y (2009) Avoid or compensate? liability for incidental injury to civilians inflicted during armed conflict. Vanderbilt J Transnatl Law 42:181

Ronen Y (2010) Superior responsibility of civilians for international crimes committed in civilian settings. Vanderbilt J Transnl Law 43:313

Sandoz Y et al (eds) (1987) Commentary on the additional protocols of 8 June 1977 to the Geneva conventions of 12 August 1949 International Committee of the Red Cross. Martinus Nijhof Publishers, Geneva

Schlesinger Panel (2004) Final report of the independent panel to review DOD detention (August 2004). Available at http://www.au.af.mil/au/awc/awcgate/dod/d20040824finalreport.pdf

Schmitt MN (2011) Investigating violations of international law in armed conflicts. Harv Natl Secur J 2:31

Shany Y, Michaeli K (2002) The Sharon case: revisiting the doctrine of command responsibility. N Y Univ J Int Law Politics 34:797

Strasberg-Cohen Commission (2011) Report of the Special Investigatory Commission (27 Feb 2011). Available in Hebrew at http://www.pmo.gov.il/PMO/Communication/Spokesman/ 2011/02/spokeshchade270211.htm

The Somalia Commission of Inquiry (Canada) (1997) Final report (2 July 1997). Available at http://www.dnd.ca/somalia/somaliae.htm

The Turkel Commission (2011) The public commission to examine the maritime incident of 31 May 2010: report part 1 (January 2011). Available at http://www.turkel-committee.gov.il/ files/wordocs//8707200211english.pdf. Last Accessed 30 Dec 2011

Tomuschat Report (2010) Report of the committee of independent experts in International Humanitarian and Human Rights Laws to monitor and assess any domestic, legal or other proceedings undertaken by both the Government of Israel and the Palestinian side, in the light of General Assembly resolution 64/254, including the independence, effectiveness, genuineness of these investigations and their conformity with international standards, UN Doc. A/ HRC/15/50 (2010) http://unispal.un.org/UNISPAL.NSF/0/B07AE44EC3B4F211852577A $5004 \mathrm{C} 709 \mathrm{~B}$

Watkin K (2004) Controlling the use of force: a role for human rights norms in contemporary armed conflict. Am J Int Law 98:1 